\title{
La Font Antiga de Crevillent, más que qanāt: la captación y almacenaje de las aguas superficiales y su relación con los molinos andalusíes
}

\author{
Josep Menargues \\ Museo Arqueológico de Villena \\ pepmenargues@gmail.com
}

\begin{abstract}
Resumen. En 2011 realizamos varios trabajos arqueológicos y topográficos en un lugar del sistema hidráulico de La Font Antiga llamado La Tanca del Forat (Crevillent, Alacant). Los resultados nos han permitido identificar e interpretar la mayor parte de las piezas y mecanismos que integraban la compleja red de canalizaciones, presas y molinos andalusís arruinados. Además del conocido qanāt, son especialmente novedosas la formas de captación y almacenaje de las aguas superficiales y su aprovechamiento para el riego, mientras cuando los molinos lo requerían. Otra importante consecuencia de esta misión ha sido la de poder establecer la primera secuencia histórica de las distintas canalizaciones presentes en el paraje. Por último presentamos una selección de los más notorios monumentos hidráulicos de este sistema dispersos por la huerta que corren serio peligro de desaparición.
\end{abstract}

Palabras clave: Font Antiga, qanāt, azud, molino, andalusí.

\begin{abstract}
In 2011, we made several archaeological and topographical works in La Tanca del Forat, in La Font Antiga hydraulic system, Crevillent, Comunitat Valenciana. The results allowed us to interpret the pieces and mechanisms of a complex ruined network of canals, dams and andalusian watermills. The capture and storage of surface water and its use for irrigation are particularly interesting. Meanwhile, water from the qanāt is used to impel the wheels of the mills. Another important consequence of this mission has been to establish a historical sequence of the canals.
\end{abstract}

Keywords: Font Antiga, qanāt, dam, watermill, andalusian.

\section{Introducción}

Nuestro trabajo se desarrolló en el término municipal de Crevillent (Alacant, Comunitat Valenciana), y tuvo por objeto el estudio de diversas construcciones abandonadas cercanas al paraje de La Tanca del Forat, en el ámbito del sistema hidráulico de La Font Antiga (Fig. 1). Después de una serie de aproximaciones descriptivas y topográficas realizadas en la últimas centurias ${ }^{1}$, eran deseables investigaciones arqueológicas que se centrasen en establecer cronologías y secuencias sobre la base de los restos materiales. Nuestra labor ha pretendido ser una continuación de las conclusiones de M. Barceló en el sector de cabecera del qanāt (Barceló et alii, 1988). Durante los meses de noviembre y diciembre de 2011 realizamos una campaña de excavaciones y mediciones topográficas que se han ido completando con prospecciones hasta la actualidad. El desfiladero de La Tanca del Forat debió jugar especial trascendencia, puesto que en ambas riberas del torrente se observan canalizaciones superpuestas y un gran número de construcciones. La orografía de esta zona angosta resulta imponente por su fragosidad y escarpes. El principal problema arqueológico que nos encontramos es que pocos lugares ofrecían potencia sedimentaria propicia donde documentar marcadores cronológicos. Finalmente nos decantamos por sondear una plataforma contigua al camino asfaltado que conduce a Els Pontets y a la antigua acequia mayor. La cons-

${ }^{1}$ Vid. Cavanilles (1797), Barceló et al. (1988), Gea Calatayud (1990), Markham (1991) y Guinot y Selma (2003). 
trucción resultó ser un molino andalusí inédito. También practicamos catas en el relleno de un muro de sillares. Paralelamente, fuimos excavando diversos tramos de acequias y, con la ayuda del nivel topográfico, restituyendo sus trazados perdidos. Por último citaremos la limpieza que efectuamos en numerosas entalladuras presentes en el sustrato rocoso cercano a estas ruinas. La lectura combinada de los resultados nos ha permitido identificar un sistema de captación y almacenaje de aguas superficiales y una instalación molinar absolutamente desconocida. Quizás lo más llamativo del conjunto sea, además del descubrimiento de dos molinos andalusíes, la sucesión de pequeños azudes, que tienen como misión recoger y concentrar todas las aguas que discurrían por el lecho del torrente para luego inyectarlas a la acequia mayor.

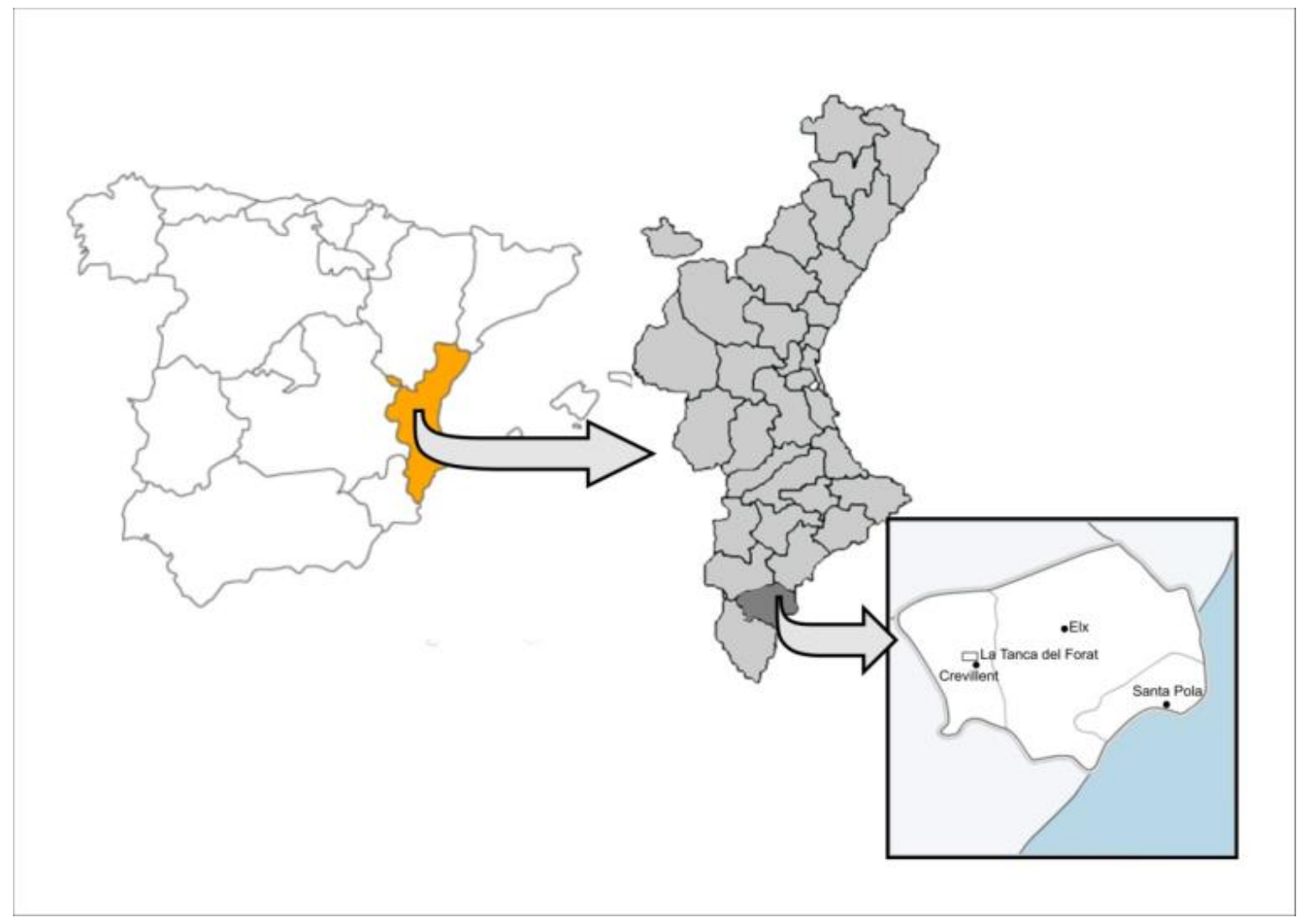

Fig. 1. Situación geográfica del área estudiada.

\section{El azud de la Tanca del Forat}

Perpendicular a la rambla, se hallan las ruinas de un azud de sillares (Fig. 2). Con un fuerte desvío oblicuo respecto al lecho, se trata de una presa rectilínea de unos $11 \mathrm{~m}$ de longitud y unos $3 \mathrm{~m}$ de altura, de las llamadas de gravedad. Apenas unas entalladuras en la roca sirvieron para cimentar el dique. A pesar que la parte central ha desaparecido, los rebajes en la roca nos permiten constatar que presentaba una sección tronco-piramidal, con una base de $130 \mathrm{~cm}$ y unos $40 \mathrm{~cm}$ en la coronación. 


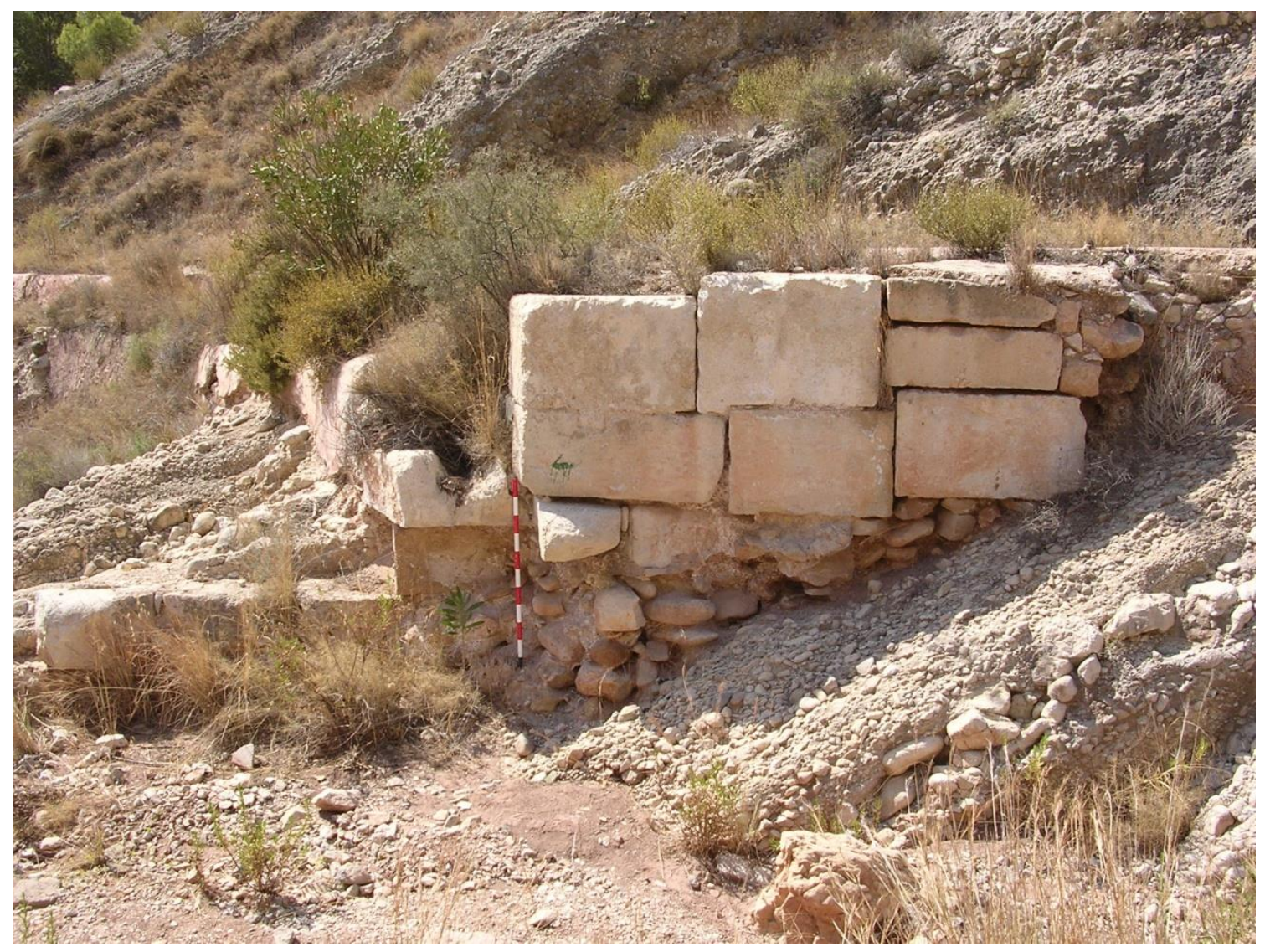

Fig. 2. Azud de La Tanca del Forat. Detalle del estribo occidental antes de la intervención.

Estas improntas nos sugieren también que el aparejo se hallaba trabado a soga y tizón. El azud obtenía mayor equilibrio y sustento frente a los empujes de las aguas del torrente mediante dos estribos laterales. El estribo de la ribera oriental se constituyó en un espolón rocoso natural tallando un relieve escalonado donde se apoyaron los sillares (Fig. 3). Dos de estos sillares paralelos, aún permanecen adheridos a la obra en sentido longitudinal respecto al muro. De las marcas pertenecientes a este estribo merece destacarse la concavidad que seguramente fue ocupada un espaldón delantero, hoy desaparecido. En lo que concierne al estribo occidental, se trata de una obra de sillares rellena de un núcleo de hormigón. Este refuerzo presenta una planta de triángulo escaleno y aún conserva ocho sillares de módulo rectangular pero de naturaleza y medidas divergentes ${ }^{2}$. Varias de estas piedras presentan pestañas con el fin de poder ser trabadas. El sondeo, lo efectuamos en la parte superior del estribo occidental. La cata resultó infructuosa. Ante el afloramiento del duro hormigón de su núcleo, decidimos abandonar la excavación. Con la intención de conocer las dimensiones y cabida del embalse que generaría este azud, realizamos una serie de proyecciones del de coronación hipotético. En este sentido, el estanque se desarrollaba más de $70 \mathrm{~m}$, rambla arriba y, la cabida de su vaso se situaría en torno a los $420 \mathrm{~m}^{3}$. Descubrimos también que la base del cárcavo del molino andalusí -que se emplaza aguas arriba de la presa- arranca de la misma cota del punto de coronación del azud. Esta circunstancia evidencia la relación entre ambos elementos: aunque el embalse se hallase a rebosar, el agua nunca anegaría el cárcavo, ni impediría la rotación del rodezno. El azud contaba con dos salidas principales: un aliviadero situado en la ribera occidental, y un canal de desagüe en el lado contrario. El primero arranca a $1,40 \mathrm{~cm}$ de altura del estribo de sillares, con una embocadura ensanchada y curvada, sin duda para amortiguar la fuerza del agua liberada del embalse. El aliviadero se conecta con el azud a través de un sillar de $85 \mathrm{~cm}$ de largo con una hendidura labrada en "U" por la que circularía el agua. Pegado a este sillar vemos otro que se adosa al estribo que tie-

\footnotetext{
${ }^{2}$ Descripciones más detalladas de estos trabajos, construcciones y materiales se pueden consultar en: Menargues $(2012,2014)$.
} 
ne una ranura vertical. Aparentemente podría tratarse de uno de los surcos sobre los que se deslizaría la compuerta, pero también cabe que sea un antiguo rebaje de un sillar reutilizado. Cada uno por su respectiva orilla, tanto el canal del aliviadero, después de atravesar la rambla por El Pont dels Moros, como el del desagüe desembocaban en la acequia mayor musulmana.

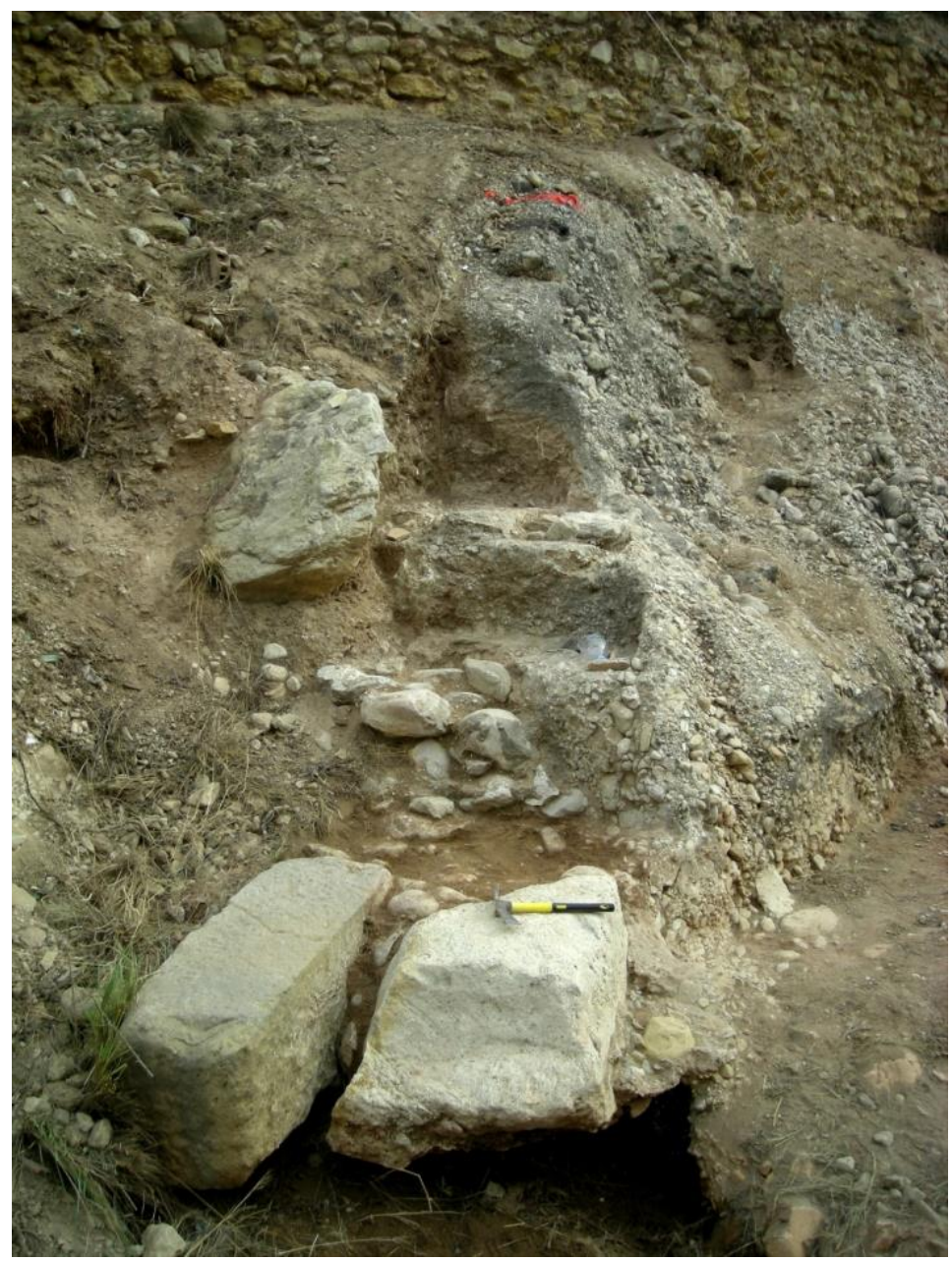

Fig. 3. Estribo oriental. Entalladuras de sillares y espaldón. En la base, canal de desagüe del azud.

\section{El molino de La Tanca del Forat}

Los restos de este molino se encuentran en el margen derecho (Fig. 4). La plataforma sobre la que se construyó el molino apenas alcanza los $80 \mathrm{~m}^{2}$ de superficie, con lados de unos $4 \mathrm{x}$ $15 \mathrm{~m}$. Destaca el muro de contención de unos $12 \mathrm{~m}$. La planta de esta terraza conforma una especie de cuadrilátero trapezoidal. El muro arranca con un basamento o zócalo visto de unos $110 \mathrm{~cm}$ de altura. Está construido con mampostería de gruesas piedras ligeramente retocadas. El zócalo se culmina con una hilera de pequeñas losas sobre la que se levanta la pared hasta más de $3 \mathrm{~m}$ de altura en sus partes mejor conservadas. Esta pared superior muestra piedras de menor tamaño. La mampostería aparece mezclada con mortero de cal. 


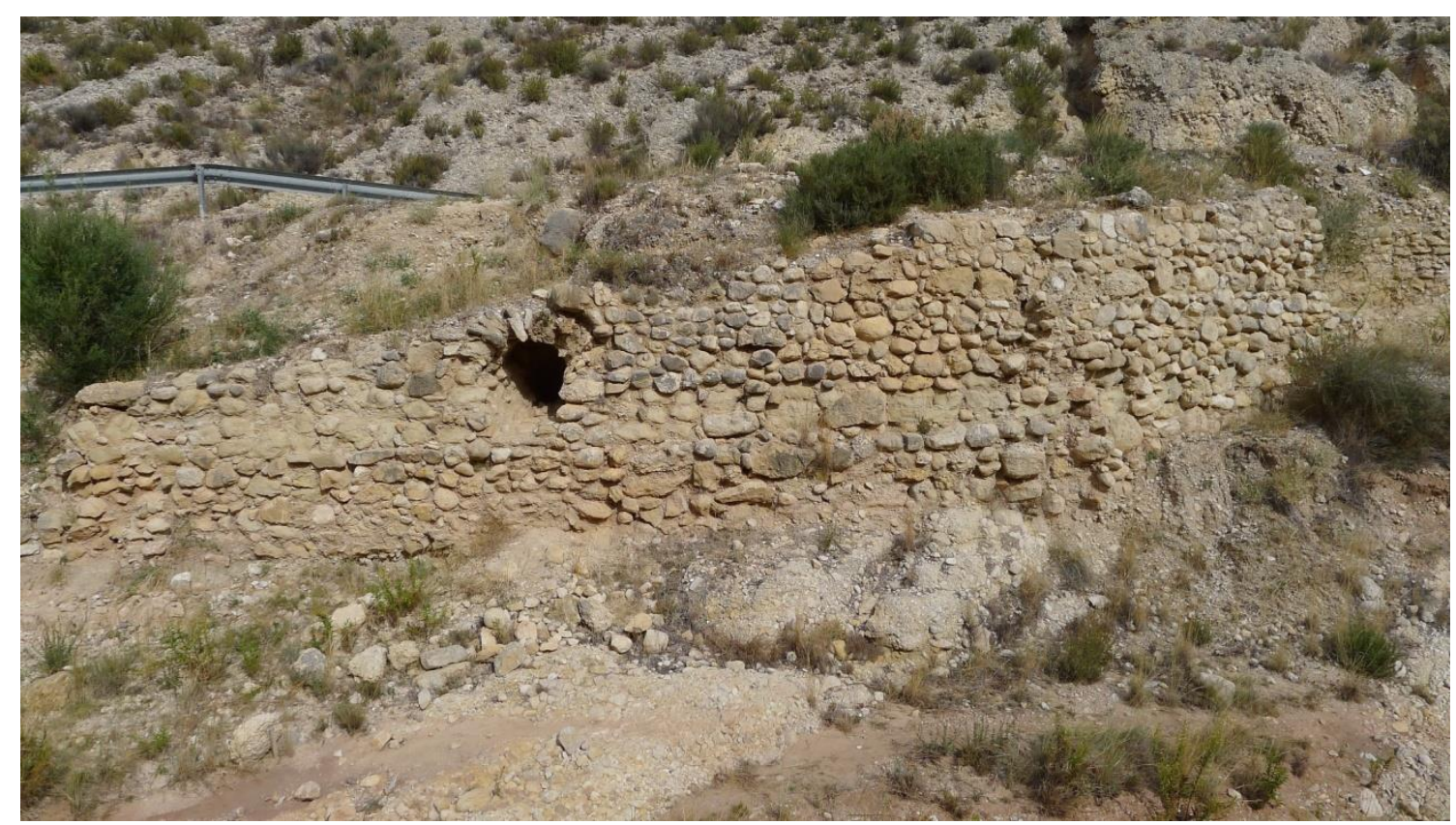

Fig. 4. Plataforma del molino de La Tanca del Forat.

Las hiladas son en general regulares, así como el tamaño de los bloques. La alta plataforma del molino en algún momento debió hallarse apuntalada mediante un robusto contrafuerte en el ángulo que mira a la rambla, tal como lo sugieren diversos salientes de piedras. El elemento más llamativo de esta pared es una pequeña hornacina o ventana que se apoya sobre el basamento y concluye formando un arco de medio punto. El arco se halla construido con pequeñas losas recibidas con yeso. La plataforma del molino ha sufrido grandes daños, especialmente en las últimas décadas, al ser trazado el camino asfaltado sobre su parte septentrional que arrasó la acequia mayor a la que estaba conectado. También se destruyeron sus paredes al crear un acceso a la rambla. En cuanto al sondeo, decir que lo efectuamos muy cerca del camino, en el poco espacio existente. La cuadrícula, desde el punto de vista arquitectónico, la planteamos con dos objetivos: documentar las características de la cimentación y el abovedado de la hornacina. Así que el rectángulo arqueológico ocupó la mitad superior de la bóveda, que al descender fue quedando descubierta. Los niveles superiores contenían gran cantidad de objetos contemporáneos y restos de derrumbes antiguos. El fundamento apareció a los 2,4 $\mathrm{m}$ y se halla compuesto por grandes cantos y grava unidos con cal. En las cotas más inferiores localizamos varios fragmentos de cerámica y huesos prehistóricos cuya procedencia y atribución se ha de relacionar con los inmediatos yacimientos de la Edad del Bronce. Sin duda, los constructores musulmanes del molino utilizaron tierras de arrastre procedente de estos poblados para rellenar la base del edificio.

La actuación arqueológica también comprendió el vaciado de la estructura arqueada u hornacina que se hallaba completamente cegada. Excavamos hasta 2,5 $\mathrm{m}$ de profundidad. Penetrar más suponía un riesgo de derrumbe, ya que nos situaríamos bajo el actual camino. Las dimensiones aproximadas de esta galería son de $140 \mathrm{~cm}$ de altura por $80 \mathrm{~cm}$ de anchura. Las paredes están levantadas con tosca mampostería. Sin embargo el suelo presenta un enlosado fuertemente cementado, sin duda para resistir la fuerza erosiva del agua. El escombro que extrajimos estaba compuesto por grandes bloques calcáreos procedentes del derrumbe interno y de los cerros conglomeráticos del entorno. A medida que avanzábamos en el trabajo, constatábamos con mayor seguridad que esta cavidad constituía el cárcavo de un molino. Una prueba de su duradera relación con las acequias fue la localización de nu- 
merosas costras o calcificaciones calcáreas como las que se desarrollan en las paredes de los canales y alrededor de los tallos de juncos y otras plantas de zonas húmedas. Pero sin duda, la demostración más evidente fue la recuperación de un fragmento de unos $30 \mathrm{~cm}$ de muela solera de caliza alógena, oscura y muy pesada (Fig. 5).

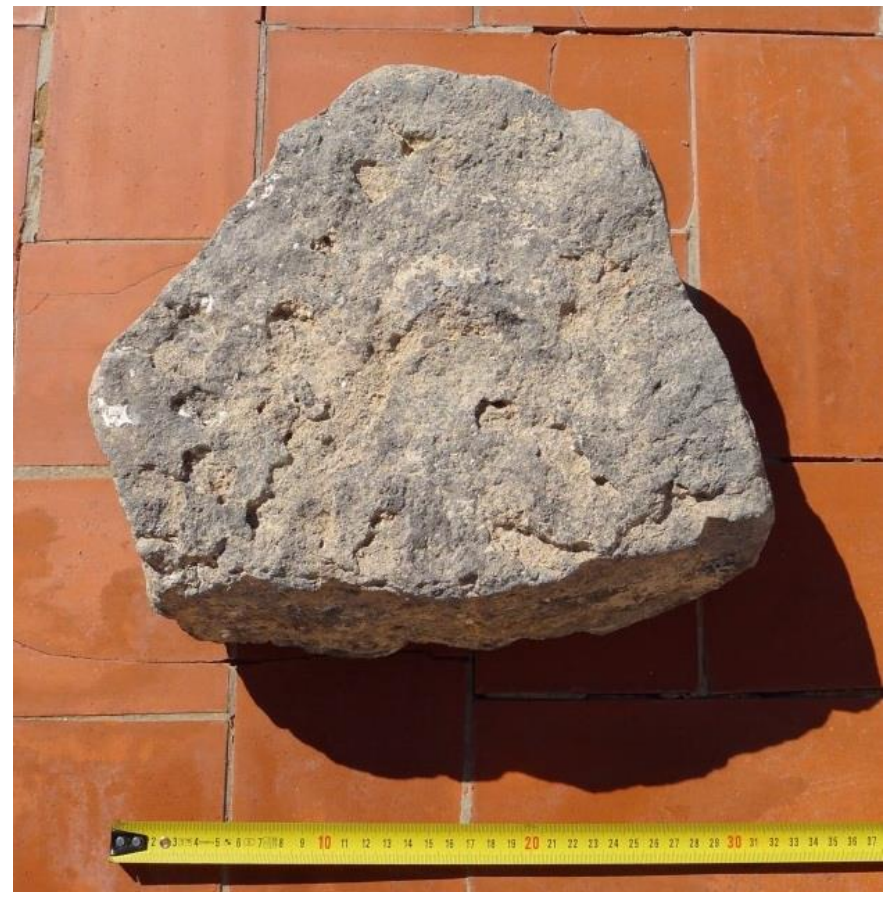

Fig. 5. Fragmento de muela hallado en el cárcavo del molino.

La muela debería alcanzar los $90 \mathrm{~cm}$ de diámetro. Tanto la tipología como las medidas del cárcavo y muela recuerdan enormemente a los molinos excavados en la antigua acequia de Rovella en València, que fueron abandonados ya en época califal (Arnau, B. \& Martí, J., 2000). Coincidrían estos datos también con la documentación islámica. En este sentido, el jurista IbnRushd del siglo XII, dictamina las disposiciones que han de regir un contrato de alquiler de un molino tomando como referencia un formulario del siglo $\mathrm{X}$, en el que, entre otras se detalla que las muelas han de medir cuatro palmos y medio $\geq 90 \mathrm{~cm}$ (Lagardere, 1991). Piedras de diámetro semejante se documentan en diversas partes de Al-Andalús, asociados a molinos pequeños, que se reparten a lo largo de las redes hidráulicas andalusíes, especialmente, las de caudales escaso (Selma, 2000). Estos pequeños ingenios altomedievales seguramente ligados a explotaciones agrícolas modestas debieron abundar en Shark-al-Andalús, pero a medida que la estructura musulmana se desintegraba fueron sustituidos por las instalaciones feudales. Tan solo parece que perduraron en las comarcas montañosas del Magreb, donde las comunidades locales siguieron haciendo uso de los pequeños ingenios hasta épocas recientes. Un llamativo paralelo con nuestro molino lo encontramos en el molino Mursiya en la región de Tagsa, dado a conocer por Carbonero (1997), (Fig. 6).

Deducimos que el molino hacia servir la rampa para obtener su energía. Fragmentada, la rampa se constituye por la propia acequia mayor que después de sortear el angosto inicia un brusco descenso que no tiene otro sentido más que lograr la suficiente fuerza motriz para mover el rodezno que se emplaza unos $80 \mathrm{~m}$ más adelante (Fig. 7). El desnivel en este tramo es impresionante, superando los $10 \mathrm{~m}$. La rampa, a la altura del casal, debió penetrar oblicuamente en el cárcavo a través de un partidor que desaparecería cuando se construyó el camino. El agua que evacuaba el molino caía directamente al embalse. Poco podemos decir sobre la habitación de la moltura. Nada se ha conservado. Tan solo apuntar la posi- 
ción cercana al medieval camino de Aspe que discurría cercano y del que aún podemos apreciar un tramo excavado en la roca a apenas una decena de metros del molino.

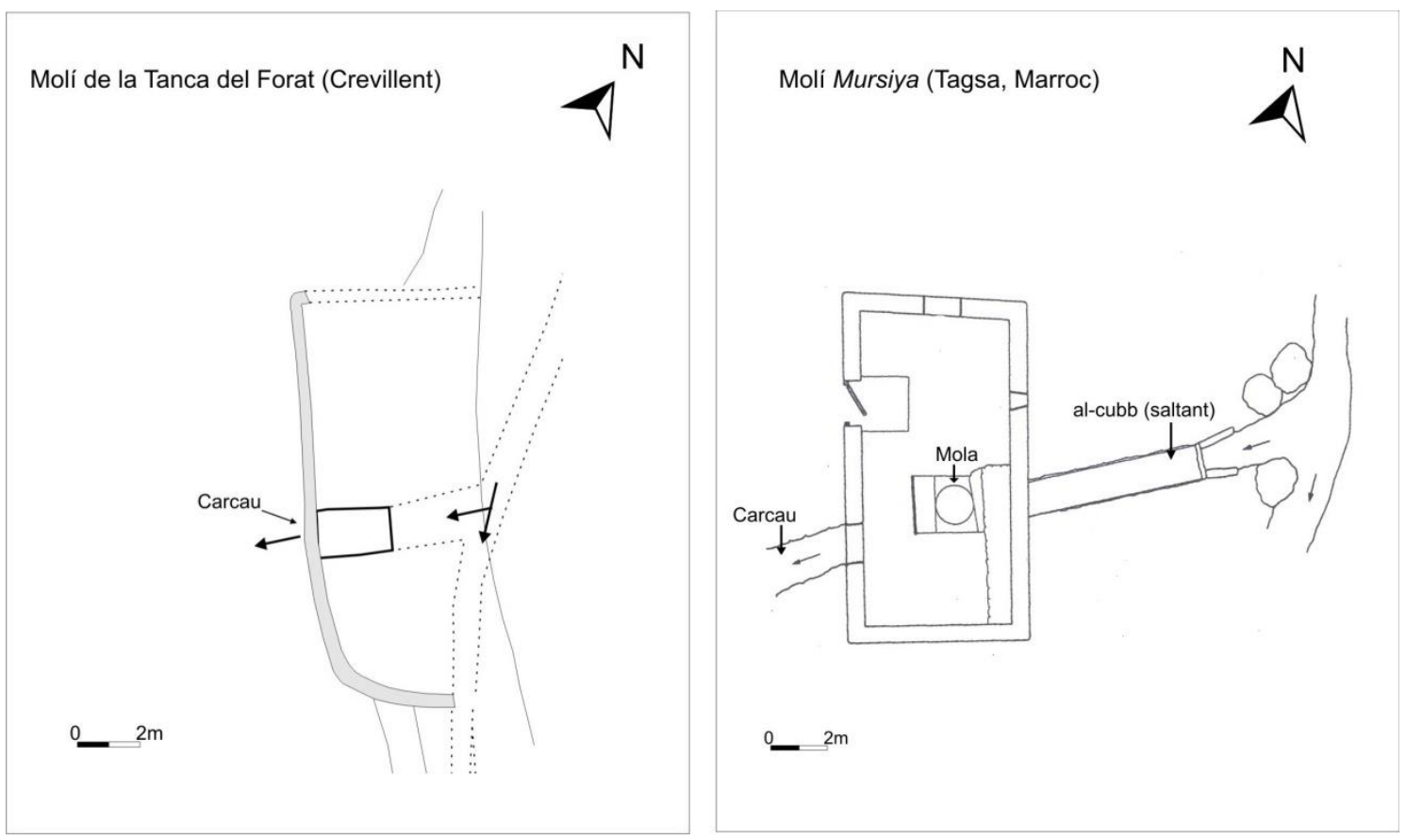

Fig. 6. Comparativa de las plantas de los molinos de La Tanca del Forat y Mursiyya.

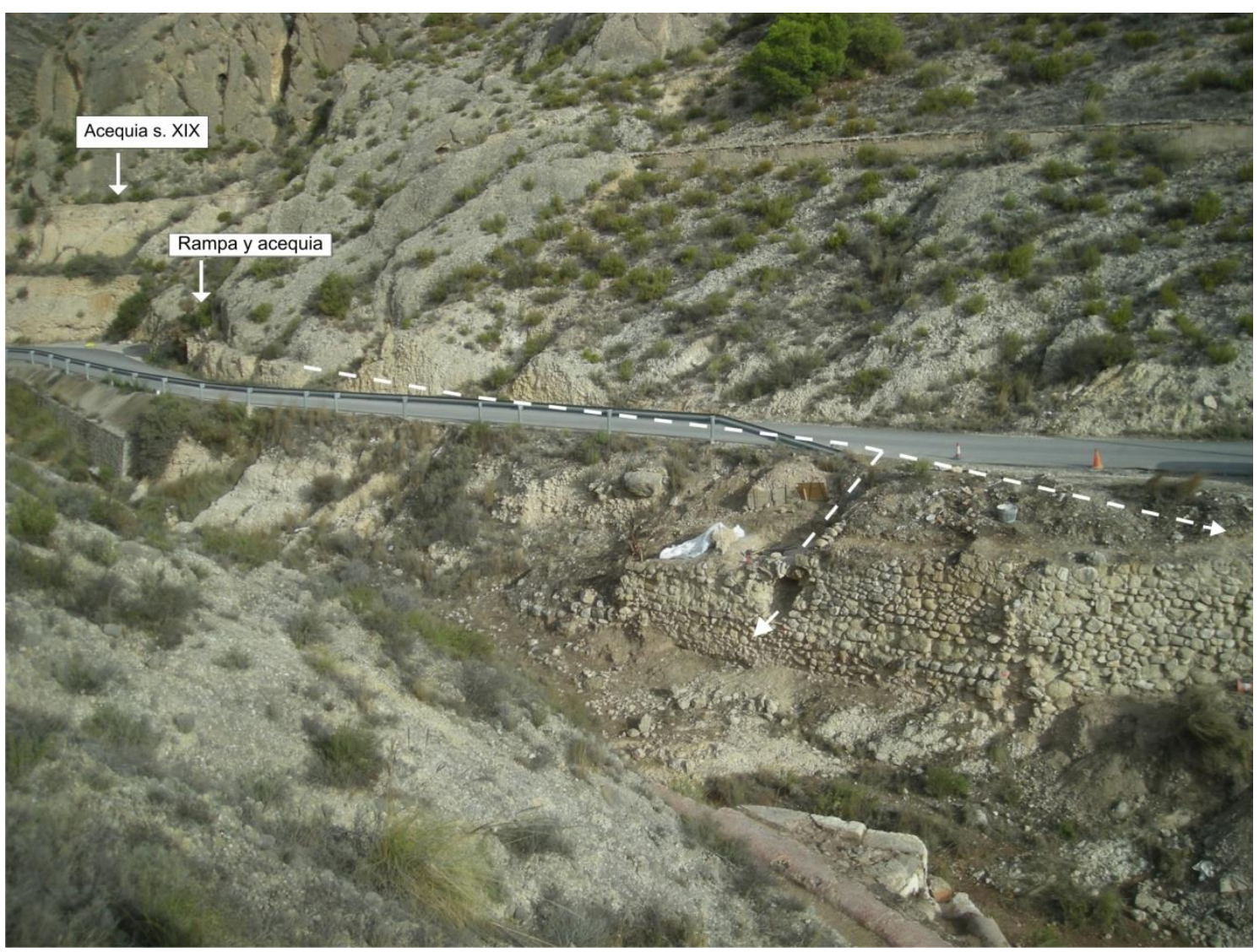

Fig. 7. Rampa del molino. 


\section{Acueducto}

La acequia mayor en época andalusí, después de atravesar la depresión de La Canyada de les Moreresutilizando el acueducto de ElsPontets - que entonces solo contaba con una planta de arcos- rodeaba los escarpes del desfiladero de La Tanca del Forat e inmediatamente después iniciaba un acusado descenso hasta el molino. Una vez superado este edificio, se inicia otro tramo de angosturas y barranquillos que la acequia sortea mediante un nuevo acueducto, esta vez menos monumental que el anterior, de solo un arco (Fig. 8). Su situación recóndita hace que sea uno de los elementos menos conocidos del sistema. Después de unas jornadas de limpieza y de algunas partes de la acequia que nos permitieron identificar sus principales funciones y secuencias, procedimos a su estudio. Es de aspecto macizo con unos $40 \mathrm{~m}$ de longitud. El arco de medio punto que lo perfora alcanza 1,56 cm de diámetro. El edificio está construido con mampostería trabada con cal y algunos sectores revoques de yeso. El módulo de las piedras es reducido, con bloques de naturaleza homogénea y parcialmente trabajados. Los filos de las piedras constatan que estos materiales son de cierta calidad, y por lo tanto proceden de canteras, no de los conglomerados cercanos o del lecho de la rambla. Consta el acueducto de seis contrafuertes en la fachada de la rambla que se le añadieron en época posterior, quizás en los siglos XVII o XVIII. La fábrica de estos puntales es de cantos rodados y yeso, unos materiales pobres, muy diferentes del acueducto. La acequia mayor que circula sobre este muro también muestra diversas refecciones, especialmente la bóveda que la cubre. Apreciamos en este canal restos del impermeabilizante rojo o grana que tanto proliferan en las construcciones de la red hidráulica crevillentina.



Fig. 8. Vista general del acueducto.

\section{E1 molino de Els Pontets}

Otro edificio novedoso es el molino hallado junto al estribo $\mathrm{N}$ del acueducto de Els Pontets (Fig. 9). El recorrido de la acequia mayor en este lugar se desarrolla en unas cotas muy elevadas. Después que las galerías del qanāt bordeen la rambla, la canalización que Barceló 
llamó Qanāt 1, continua entre túneles y sectores descubiertos a través de la loma de Les Moreres. Al llegar al borde de la depresión de la Canyada de les Moreres realiza un enorme declive que finaliza en el estribo del acueducto de Els Pontets.

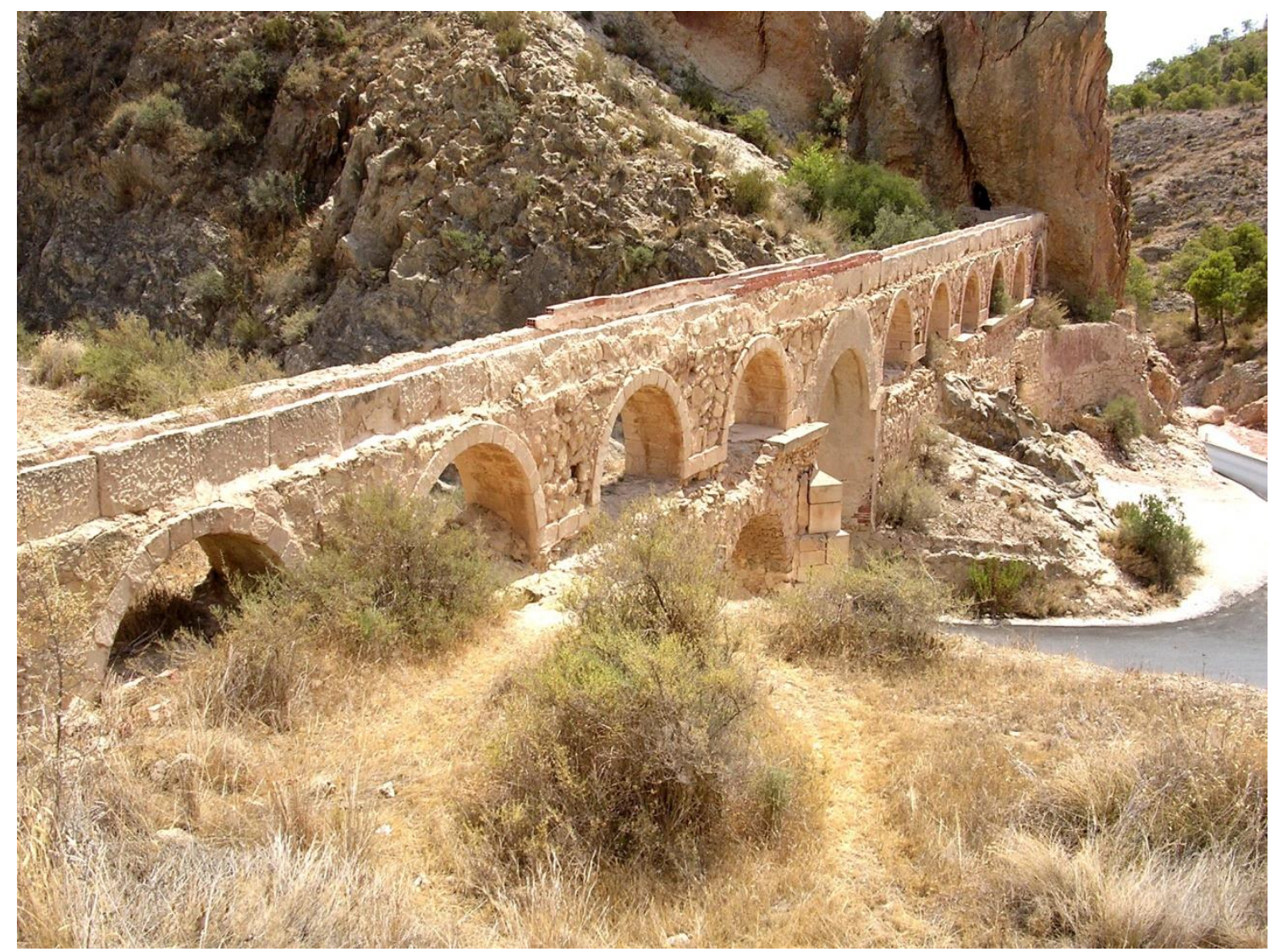

Fig. 9. Acueducto de Els Pontets. En primer término, la plataforma del molino

En este lugar observamos los restos constructivos del salto, donde debería ubicarse el cubo del molino que comentamos. En la base, se detectan migrados vestigios de un pequeño casal, más reducido aún que el de La Tanca del Forat. El agua que vertía su cárcavo, una vez había movido el rodezno, suponemos que se reconducía a la acequia mayor, aunque también podría desaguarse a la rambla, donde los azudes la retomarían. Lo que parece claro es que, como su vecino, se hallaba desconectado de espacio irrigado alguno. Ninguna pista material nos resuelve el dilema. No conocemos ninguna cita referente a este molino. Teniendo en cuenta su ubicación en el recorrido medieval, debemos pensar que fue abandonado al menos en tiempos de la conquista del siglo XIII. Visto en conjunto, la conclusión más importante sea por ahora que este tramo aéreo de ElsPontets, que finaliza más abajo en el molino de la Tanca del Forat, indudablemente se proyectó con la intención de conseguir suficiente desnivel para obtener potencia suficiente para impeler la maquinaria de los molinos. Es una instalación pragmática, localizada en un tramo extremo, aprovechando el escaso caudal y la orografía.

\section{Los molinos medievales de Crevillent}

Después del descubrimiento de este complejo manufacturero desconocido, se hacía necesaria la revisión de todo cuanto sabíamos sobre los molinos en la localidad. Desde la Baja 
Edad Media hasta el siglo XIX los principales molinos se ubicaron en el paraje del Canastell. En época mudéjar este distrito se llamó La Talla o La Tàlia, según nuestras investigaciones (Menargues, 2012). Se trata de una zona al norte del núcleo urbano, con un desnivel moderado, cercana a los huertos de los arrabales. El camino viejo de Aspe, una importante arteria de comunicación anterior al siglo XVIII, discurre vecino. Tres molinos se llegaron a establecer, el de Dalt, el d'Enmig i el de Baix (Fig. 10). En los siglos XIV y XV se cita un solo molino, cuya propiedad acostumbró a ser de la Corona, bien del patrimonio real, bien de la familia de los reyes de la Corona Catalano-aragonesa. Se solía arrendar a musulmanes de la aljama local por periodos de un año ${ }^{3}$ En la primera mitad del siglo XIV se construyó un nuevo molino a instancias del infante Martí, a la sazón propietario de la villa (Ferrer i Mallol, 1988). Pero este se levantaría pegado a la Puerta de l'Adarop, uno de los accesos principales de la villa murada (Menargues, 2005). Posteriormente, en el siglo XVI el fuerte crecimiento demográfico, propició la construcción de un nuevo molino en la Talla. I por último, a principios del siglo XVIII se fundó el último de ellos en el lugar (Puig Fuentes, 2000). Uno de los principales problemas que plantean estos casales del Canastell es su identificación y secuencia histórica. Exteriormente todos presentan elementos típicos de los molinos de la Edad Moderna valenciana. No sabemos si este núcleo se desarrolló a partir de antecedentes andalusíes pre-feudales, o se inició después de la conquista cristina, con la construcción del nombrado molino bajo-medieval de la Talla. A excepción de los de El Canastell y del nombrado molino del Infante Martí, no teníamos constancia de otros molinos. Tan solo una nota indirecta, que ahora veremos, permite esbozar los molinos de la cabecera del manantial que hemos descubierto.

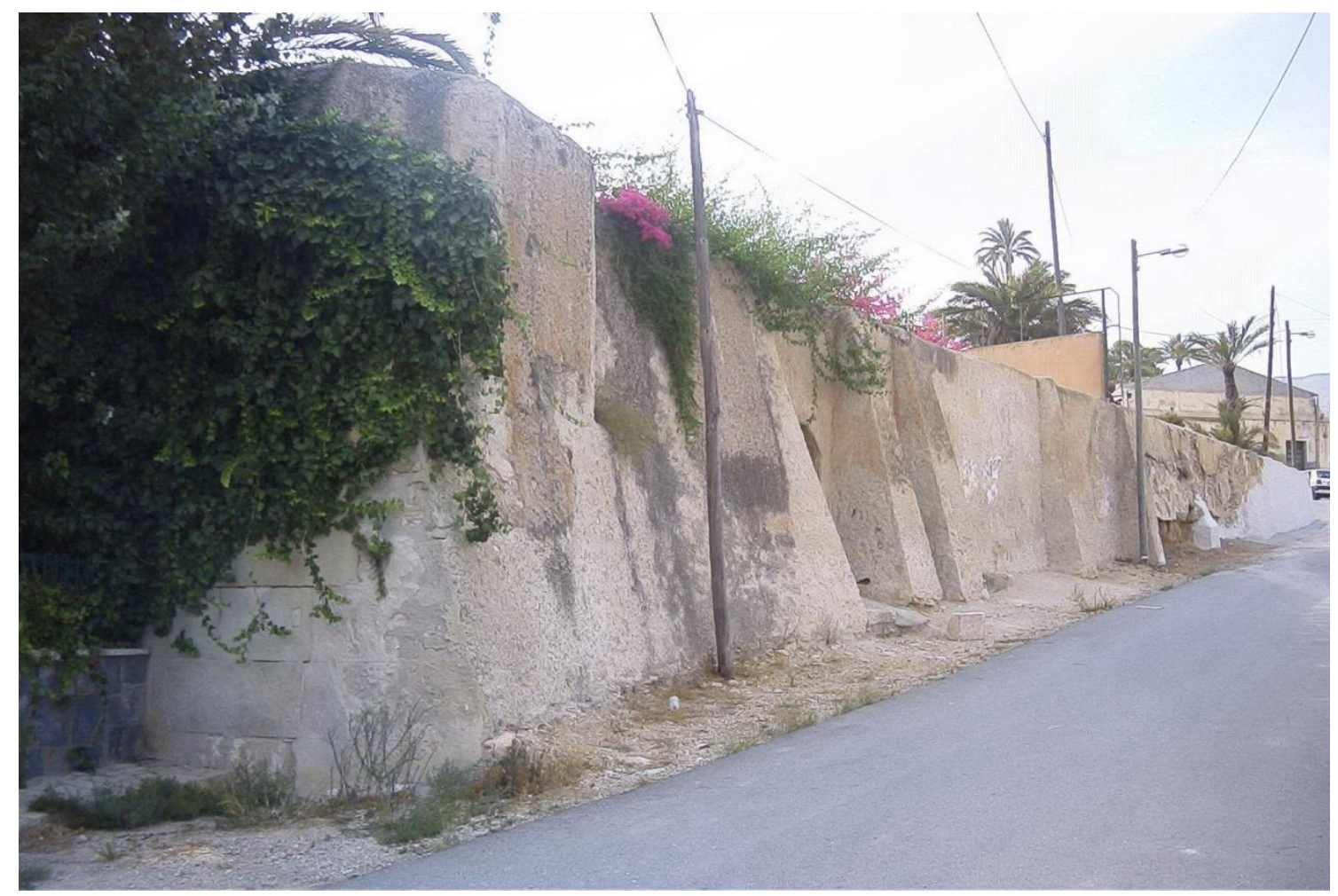

Fig. 10. Molino de Baix, en la zona de El Canastell.

${ }^{3}$ La relación de documentación archivística referente los molinos mudéjares y moriscos puede verse en mi último trabajo (Menargues, 2014). 


\section{Molinos en la cabecera}

Según M. Barceló, la administración feudal fomentó la implantación de molinos en las áreas de montaña próximas a las fuentes, donde el caudal del agua es seguro y abundante (Barceló et alii, 1988, b). Se intentaba de esta forma privilegiar la molienda, que generaba grandes beneficios fiscales, sobre la agricultura. Este rígido modelo presenta numerosas excepciones en todo el territorio valenciano, siendo hoy en día, totalmente superado ya que la realidad deviene mucho más compleja (Glicket alii, 2000). En nuestro caso, los molinos del Prao y Morales que ocuparon la cabecera no se construyeron hasta mediados del siglo XIX, con la desaparición del monopolio señorial (Oliver Narbona, 1983); (Menargues, 2014). No teníamos noticias en este lugar de industria anterior a este siglo. La revisión de la documentación sacó a la luz varios antecedentes, pero lejos de considerarse empresas feudales, serían de fundación musulmana. En efecto, todo apunta que en la cabecera del manantial de la Font Antiga se trazaría un circuito molinar ya desde el mismo momento de construcción del qanāt. En la década de $1980 \mathrm{M}^{\mathrm{a}} \mathrm{T}^{\mathrm{a}}$ Ferrer i Mallol (1988) reseñó un mandamiento de la Cancillería de Jaume II fechado en 1318 que resultaba muy interesante por dos razones, una por ser la más antigua cita de la red hidráulica -Céquia de Crevillén-, y por aludir a una cierta infraestructura molinera en la montaña ${ }^{4}$. El documento trata de la autorización que el monarca otorga al jurista de Orihuela Llorenç Fritós para la construcción de un molino.

Fritós hacía tiempo que había solicitado una compensación inmobiliaria a cuenta de 30.000 sueldos que había prestado a la Corona. La resolución a su favor otorgaba la posesión en la Sierra de Crevillent de un salto de agua -saltu aque o saltum molendinum- . El valor de esta heredad ascendía a 150 sueldos, que habrían de ser descontados del valor de la deuda contraída. El rey se reservaba el dominio directo y los derechos de luismo y fadiga. El lugar donde se establecería se llamaba en aquella época Zabara, situado juxta montanea. El topónimo desapareció en la Edad Moderna, pero pocos lugares se revelan más aptos para ser identificados con aquel lugar como la zona que hemos estudiado a La Tanca del Forat. El salto al que alude el documento bien podría ser la acusada rampa de nuestro primer molino excavado, o incluso el que se observa junto a Els Pontets. El molino de Llorenç Fritós parece que no llegó a levantarse, puesto que no aparece ninguna mención posterior salvo la que hemos comentado anteriormente de La Talla. Tampoco en nuestras prospecciones hemos localizados restos materiales bajo medievales asociados a las ruinas. Con todo, lo que dejan entrever estos datos es que en tiempos de la conquista catalana existía ya un complejo molinero en la zona -constituto-, muy posiblemente abandonado o destruido por las guerras. Por lo visto, la empresa de 1318 trataba de restaurar unas instalaciones musulmanas preexistentes.

\section{Azud de La Tanca dels Nicolassos}

Un centenar de metros aguas arriba del primer azud y molino, cerca del angosto conocido como La Tanca dels Nicolassos, se levantó otra. A diferencia de la anterior, esta obra ya fue detectada y citada por M. Barceló (Barceló et alii, 1988) y posteriormente por S. Selma y E. Guinot (2003). El azud se halla en la actualidad totalmente arrasado, después que en la década de 1990 se dejara expedito el cauce de la rambla para controlar las avenidas equinocciales (Fig. 11). A pesar de su destrucción, son perfectamente deducibles las dimensiones del muro que constituía el azud, ya que permanecen las huellas de su cimentación que no son otras que un duro estrato o veta de dura caliza. En efecto, los constructores aprovecha-

${ }^{4}$ La transcripción completa de este documento figura en Menargues (2014). 
ron la formación geológica de espesor variable que atraviesa la rambla en sentido oblicuo para que sirviese de dique de derivación. No sabemos si todo el muro era pura roca o si estaba rematado por obra de fábrica, el caso es que se desarrolla de igual figura que el azud de La Tanca del Forat. El dique tenía unos $12 \mathrm{~m}$ de longitud y unos escasos $2 \mathrm{~m}$ de altura, por unos $120 \mathrm{~cm}$ de espesor en su base. Constaba también de un aliviadero que aún permanece excavado en la roca en la ribera occidental, para lo cual se tuvo que picar una zanja de $1 \mathrm{~m}$ de profundidad. El cajero de este canal tiene por lo regular $55 \mathrm{~cm}$. Este embalse se halla a una cota superior al de La Tanca del Forat, así que permite liberar agua por gravedad hacia este último y así mismo, hacia la acequia mayor, mediante sendas canalizaciones.

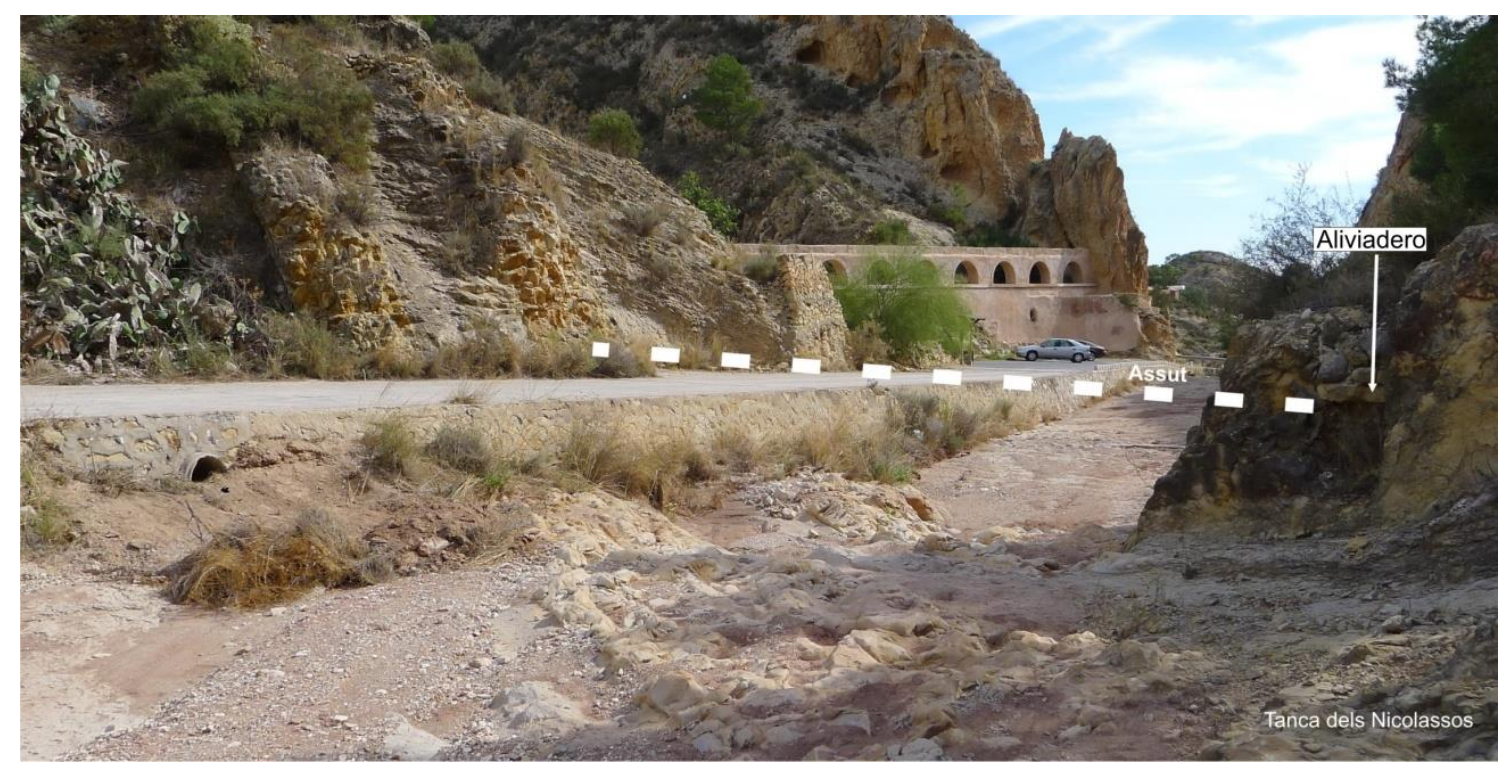

Fig. 11. Azud de La Tanca dels Nicolassos.

\section{Azud de la Séquia Fonda}

Otorgamos este nombre al tercero y más meridional de los azudes localizados en la zona de cabecera por hallarse cercano al lugar homónimo, el último desfiladero que ha de superar la acequia en su camino hacia la llanura (Fig. 12). Se justifica este nombre debido a que dicha acequia mayor discurre encajada en diversos surcos tallados en la roca. Los rebajes, desmontes y trazados son numerosos, prueba de que a lo largo de la historia ha cambiado varias veces su recorrido. El muro del azud, se levantó aprovechando un estrecho curvado y rocoso de la rambla. La obra que se asentó sobre el cauce se encuentra totalmente perdida. Su longitud no superaría los $8 \mathrm{~m}$ y nada podemos aventurar respecto a su fábrica ni altura, pero dado lo limitado del espacio, es de suponer que no tendría una gran capacidad de almacenamiento. Como en los casos anteriores, se trazó de forma oblicua al cauce, teniendo su ángulo más agudo hacia la ribera oriental. En esta orilla se asoman aún restos de una conducción abovedada realizada en mampostería de yeso de unos $50 \mathrm{~cm}$ de ancha por 40 de alta. Aún a pesar de estar prácticamente colmatada, se adivina que su función era la de transportar el agua captada por el azud hacia la acequia mayor. Posiblemente este canal de trasvase procedía del aliviadero desaparecido, que, a diferencia de los anteriores diques, debió situarse en el lado oriental. Arbustos, aterramientos, y obras de distinta índole y época han desfigurado el área. No obstante, es posible recomponer las dimensiones y el trazado de este canal secundario ya que es muy rectilíneo y marcado en la roca. Ciertos fragmentos de la acequia del azud se fabricaron con piezas de caliza con cajero de 21 x $21 \mathrm{~cm}$ y se colocaron allá donde no se daban las condiciones para encajar el canal en la roca. La acequia de trasvase que se deriva de este azud produce el efecto de discurrir "cuesta arriba", remon- 
tando y contorneando la peña persiguiendo la acequia mayor que se sitúa paralela a ella pero a un nivel superior. Ni que decir tiene que se trata de un efecto óptico. Como en tantos otros lugares, fue necesario utilizar el nivel topográfico para comprobar que era al contrario, lógicamente el canal subsidiario avanzaba en desnivel decreciente hacia la acequia mayor y hacia la localidad. Junto a las marcas de la infraestructura hidráulica, se constatan numerosas improntas de cantería preindustrial. Pendiente de un estudio profundo, todo indica que las calizas areniscas que proporcionan estos sedimentos sirvieran para fabricar y suministrar piezas de canal y losas para toda la obra. Por otro lado, también se advierte excavada en la roca la senda de mantenimiento de la acequia, así como otras muchas y diversas huellas antrópicas de difícil interpretación.

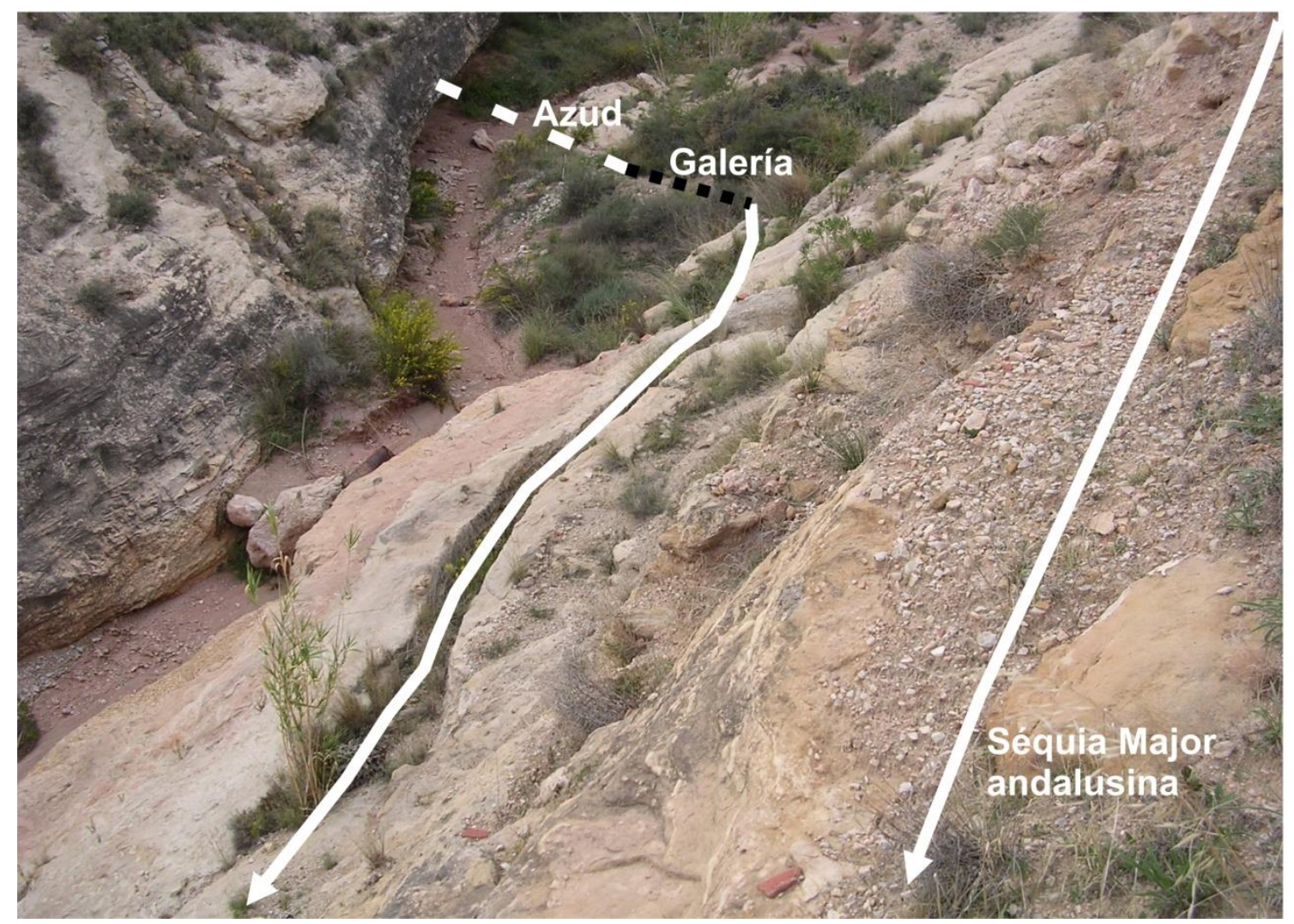

Fig. 12. Azud de La Séquia Fonda.

\section{Puente y Azud de La Terrera}

En el camino que conduce al Colomà del Castellà, justo sobre el acantilado que acoge los pozos del manantial de La Font Antiga existe un puente muy macizo, con un solo arco, que presenta una pequeña galería que lo atraviesa en toda su longitud (Fig. 13). Sin duda debió acoger algún encañado, aunque ahora no quede ni rastro de tuberías. El conducto, bastante irregular, apenas mide $18 \mathrm{~cm}$ de diámetro. Por la pendiente y dirección que lleva, debería proceder de la rambla que se asoma hacia La Font Antiga. Posiblemente, antes de llegar al precipicio, se levantaba un pequeño dique que derivaba el agua hacia el camino, y de aquí al puente. No hemos encontrado restos fiables que nos indiquen la dirección que seguían estas tuberías más allá del puente, pero es de suponer que desembocasen en alguna de las galerías, azudes, o acequia mayor del qanāt. Tan solo detectamos un segmento colgado de un diminuto canal de mampostería y cal, muy parecido a la acequia mayor andalusí que discu- 
rre por el talud occidental de la rambla, justo por encima del Qanāt 2. La cronología de este conjunto es dudosa, pero el tipo de fábrica del puente, con grandes bloques, cal y el arco de medio punto rebajado, recuerda mucho a las obras andalusíes de la zona. Además el camino, formó parte de la red viaria medieval, siendo la principal ruta comercial y trashumante para acceder al medio Vinalopó.

Estos son los restos más evidentes e interpretables de obras de captación de aguas superficiales que hemos localizado en el cauce de la cabecera. Existen muchas más improntas y ruinas que sugieren realizaciones similares, pero la prudencia investigadora hace aconsejable reservar su publicación.

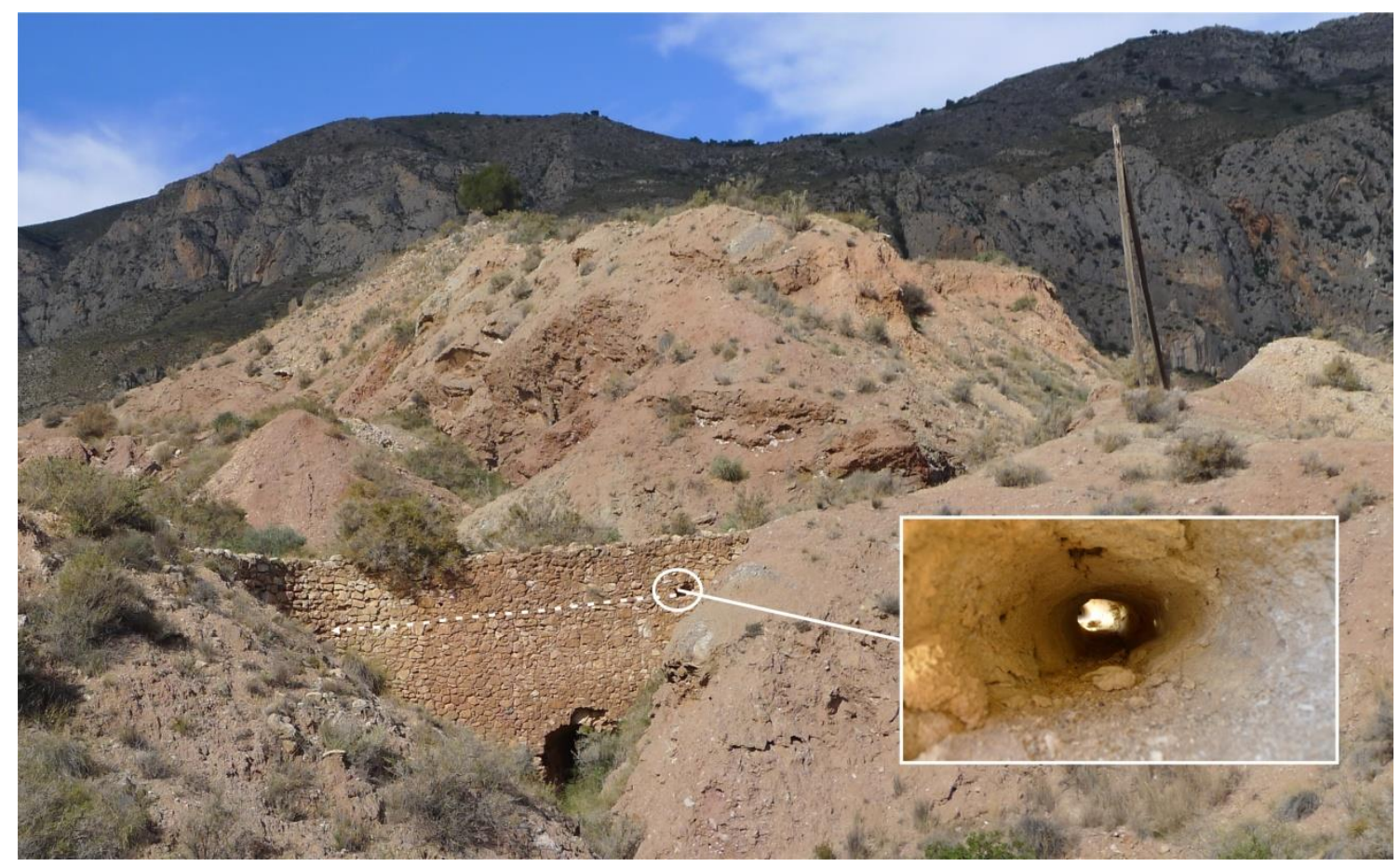

Fig. 13. Puente de La Terrera con indicaciones y detalle de la galería de caños.

\section{Azudes que garantizan el suministro}

Una serie de azudes se disponían a lo largo del torrente por el que descienden las canalizaciones del qanātde La Font Antiga. A diferencia de otras áreas valencianas en donde las paradas y balsas asociadas a molinos proporcionan el caudal necesario a los rodeznos (Selma, 1993), los azudes locales servían para suministrar agua a la red de riego, mientras la acequia principal se hallaba impeliendo las muelas. Estos azudes carecían de huertos asociados. Eran circuitos fabricados para no dejar escapar ni una sola gota. Tan solo liberaban agua, cuando el canal principal lo requería. Este sector abrupto y estrecho que hemos estudiado debió ocasionar numerosos problemas de erosión y fugas a los pobladores musulmanes y a los posteriores colonos cristianos. La construcción en el lecho de la rambla de varios embalses consecutivos y conectados vendría a paliar estos problemas congénitos (Fig. 14). 


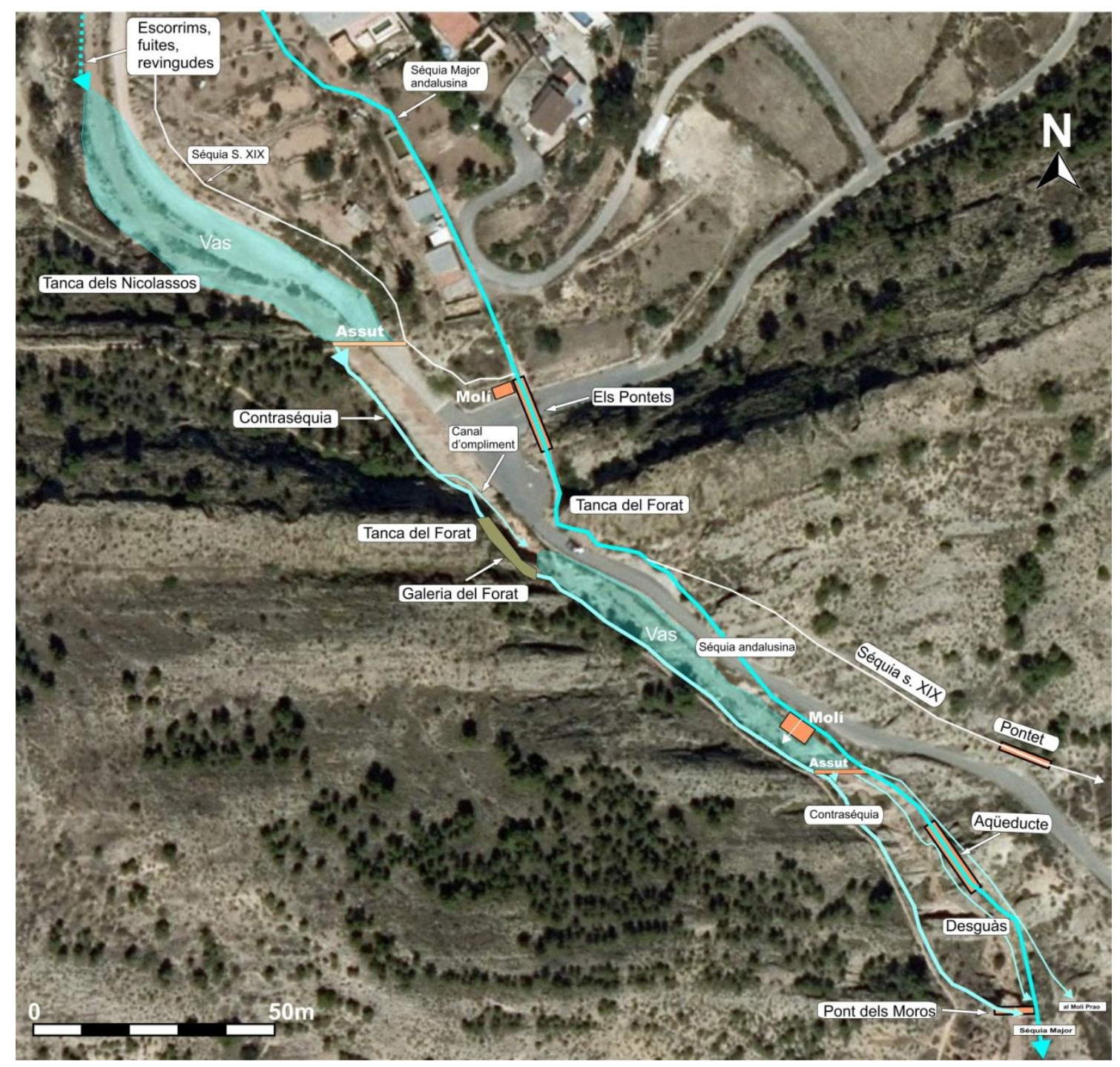

Fig. 14. Sistema hidráulico en las inmediaciones de Els Pontets.

Dado que la estrechez orográfica no permitía desarrollar grandes depósitos, se optó por construir pequeños estanques escalonados. Los azudes servirían para apropiarse de las aguas de la escorrentía subálvea, así como de los excedentes estacionales que rebosaban por las acequias y galerías. También servían para acopiar las valiosas aguas de pequeños arroyos - ullals. Las paradas actuaban como cuenca de decantación, propiciando la precipitación de los sedimentos más groseros hacia el fondo. De esta manera el agua retenida, cuando manaba por los aliviaderos, discurría limpia y cristalina, apta para mezclarse o sustituir, en tanto durase la molienda, a la que normalmente procedía del qanāt. Más al S de La Séquia Fonda no hallamos evidencias de otros azudes o presas con semejante funcionamiento. Las pérdidas a partir de este punto se dejarían al azar del aprovechamiento de las comunidades de regantes 5 .Aunque de momento solo es una especulación ya que no contamos con pruebas fiables, creemos que en los azudes de Nicolassos y Forat se vertía el agua procedente del llamado Qanāt 2. Hemos detectado rebajes en la roca de antiguas acequias y restos de

\footnotetext{
${ }^{5}$ En efecto, salvo estos ejemplos que citamos, el resto de barrerasque se levantaron el torrente de la Ramblafueron directamente para el riego, no para la acequia mayor. La documentación de la Edad Moderna nos habla, por ejemplo, del Açuch de la Lèdua, que construyó el Consell local. También figuran distintos topónimosárabes y catalanes que nos ilustran sobre la riqueza y variedad de las construcciones, p. e. Raffa, Moçayvaret, Açabaya... Sobre la toponímia árabe local, vid. Menargues (2009).
} 
galerías que apuntan en este sentido. De manera que en estos depósitos se concentraba el agua, posiblemente menos abundante a tenor de las menores dimensiones de los cajeros, de la filtración cercana al pozo principal. Hará falta profundizar en la investigación. Otra pieza que ha pasado desapercibida y que se halla ligada al aprovechamiento de las aguas superficiales y funcionamiento de los azudes es la contra-acequia -contraséquia- (Fig. 15). Este canal que discurre por la ribera occidental conecta los dos azudes, y después, superados ambos, conduce el agua de los mismos hasta El Pont dels Moros y finalmente la trasvasa a la acequia mayor que desciende siempre por el lado oriental. La contra-acequia tenia también la misión de retener los excedentes haciéndolos divagar a lo largo de la montaña mientras el flujo se normalizaba. Era finalmente una especie de bypass que en caso de necesidad permitía a las aguas de la acequia mayor circunvalar el complejo molinero (Glick et al., 2000).

\section{Balsas y aljibes}

Otros sistemas históricos de captación y almacenaje de las aguas superficiales lo constituyen determinadas balsas de riego y multitud de aljibes de agua potable que se esparcen por la huerta crevillentina. G. Escolano testimonió centenares de cisternas en nuestra comarca, que eran financiadas caritativamente por los propios ciudadanos musulmanes (Escolano, 1611). No es ahora el momento de comenzar una relación pormenorizada. No obstante ante el inminente peligro de destrucción definitiva, vemos necesaria la publicación sucinta de los posiblemente más monumentales y antiguos edificios de este tipo en la comarca. Se trata del Recinto de Els Banyets y del Aljibe del Cipré.

\section{1 Els Banyets}

En plena huerta crevillentina y vecinas de la acequia mayor de origen andalusí que se dirige a la partida del Botx, se encuentran las ruinas de un depósito o balsa llamado Els Banyets (Fig. 16). Se trata de una construcción pseudo-rectangular fabricada en durísimo hormigón de cal y grava. Tres lienzos más o menos roídos por la erosión y las agresiones antrópicas formando una " $\Pi$ " en planta, nos permiten tomar algún dato. La principal de estas paredes alcanza los $28 \mathrm{~m}$ de longitud, mientras que las dos restantes se quedan en $18 \mathrm{~m}$. La altura máxima de los restos alcanza los $2,5 \mathrm{~m}$. Aún conserva cuatro contrafuertes en su lado $\mathrm{N}$, también de la misma fábrica. El grosor aproximado de las paredes es de $90 \mathrm{~cm}$. Colmatado el recinto desde antiguo, tradicionalmente en su interior se han cultivado olivos y algarrobos. Es muy probable que en siglo XVII el edificio se hallara ya abandonado. En diversos protocolos notariales y legajos de aquella centuria y la siguiente se hace referencia a la Partida del Baño y los Baños. Creemos esta nomenclatura responde más bien la morfología de las ruinas, con espacios cuadrangulares, que a ojos de las personas de la época evocaban recintos o bañeras, que a un auténtico balneario. Tampoco parece probable que las ruinas de Els Banyets se correspondan con una balsa de riego convencional de alguna hacienda islámica, puesto que no existen noticias de las mismas más allá del área periurbana. Su ubicación a más de $4 \mathrm{~km}$ del manantial, cerca ya de los límites del área irrigada de Crevillent, sugiere más bien que se trate de algún depósito de concentración y almacenaje de aguas de la cola del sistema. Otra posibilidad es que sea una de tantas albercas cercanas a caminos que se construyeron en época califal. B. Pavón levantó plano de una junto al puente de Vallehermoso en la calzada que unía Córdoba con Madinat al Zahra que recuerda muchísimo a la nuestra (Pavón Maldonado, 1999). 


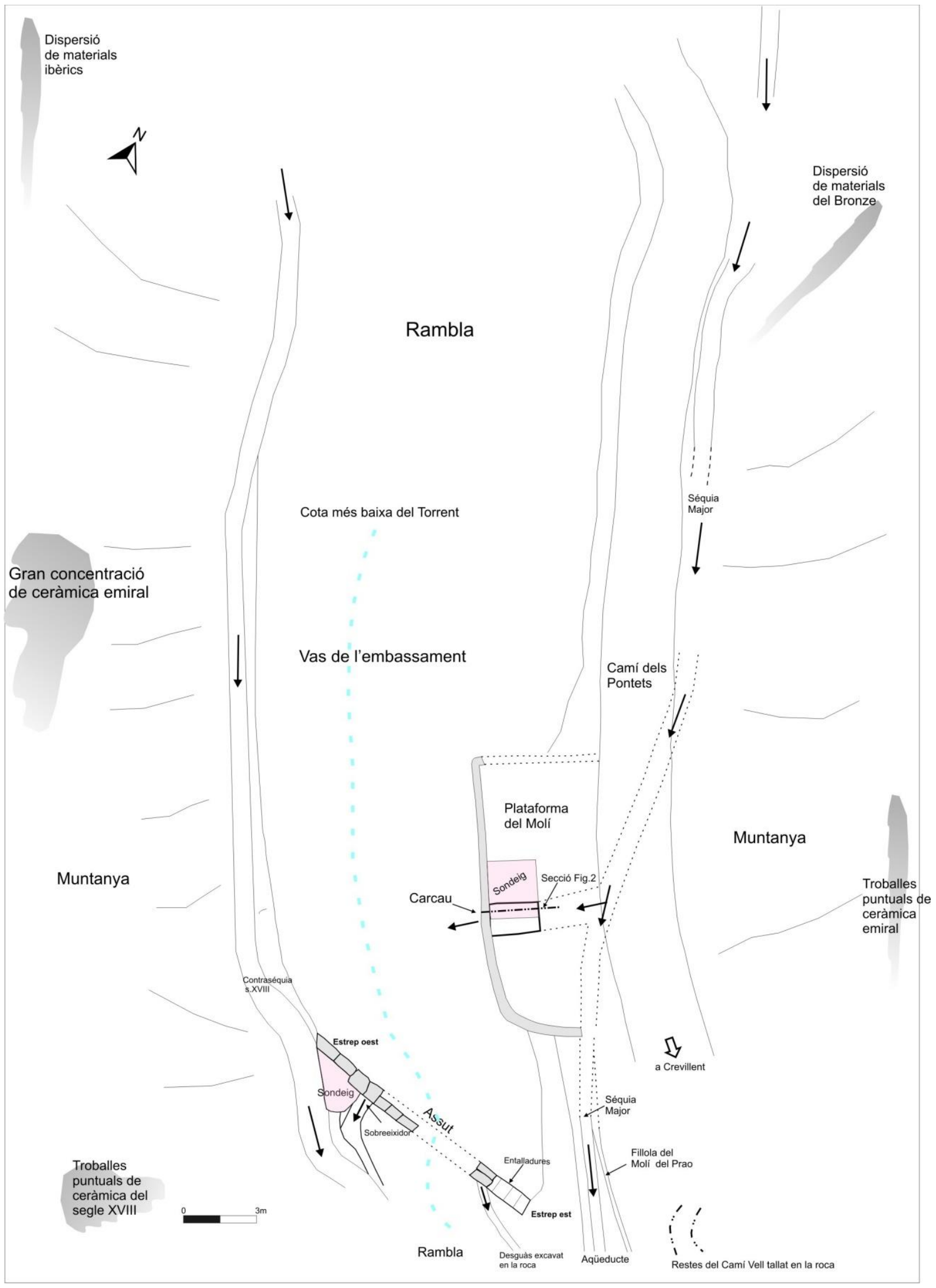

Fig. 15. Conjunto de La Tanca del Forat. 


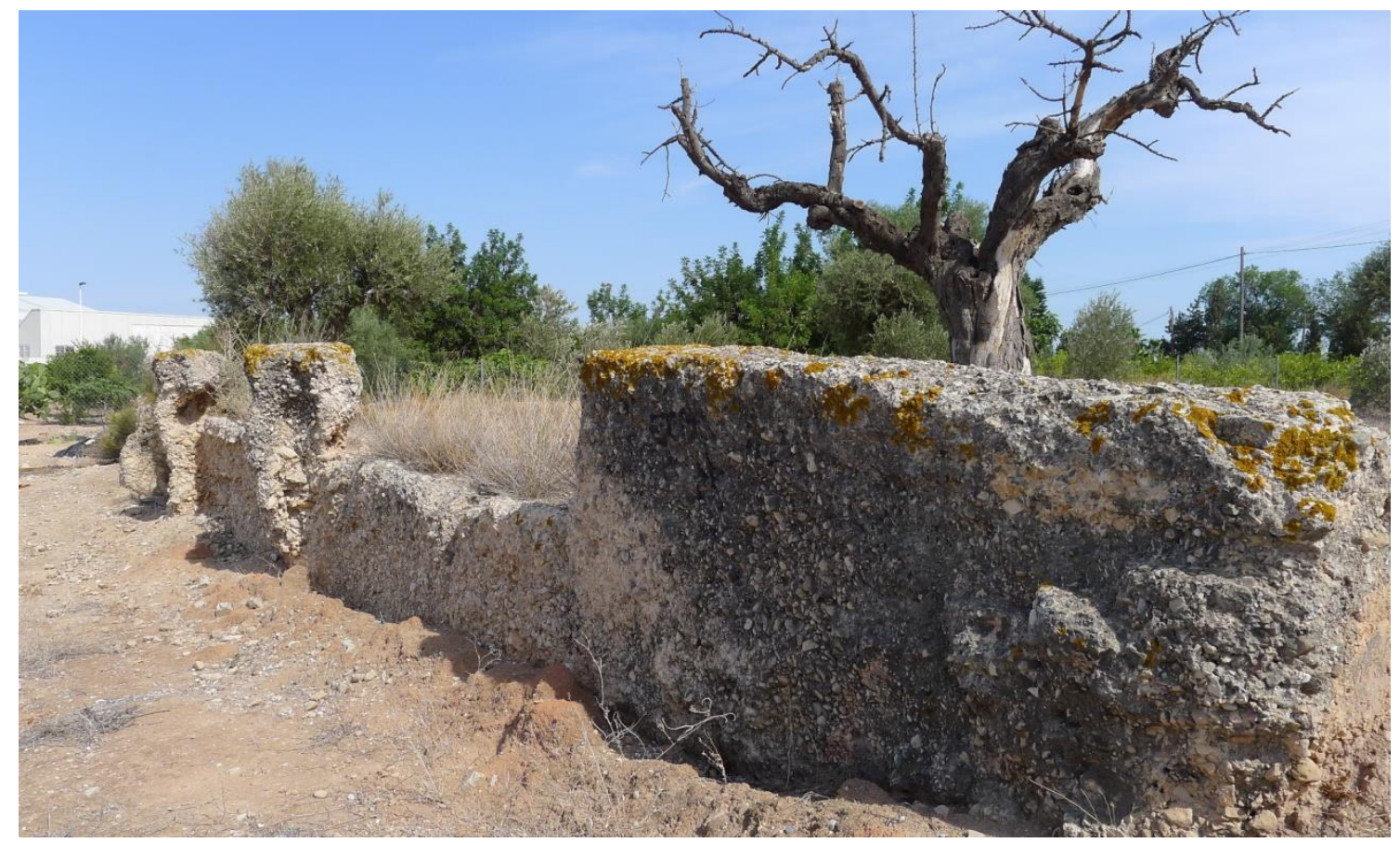

Fig. 16. Ruinas de Els Banyets. Muro y contrafuertes del lado norte.

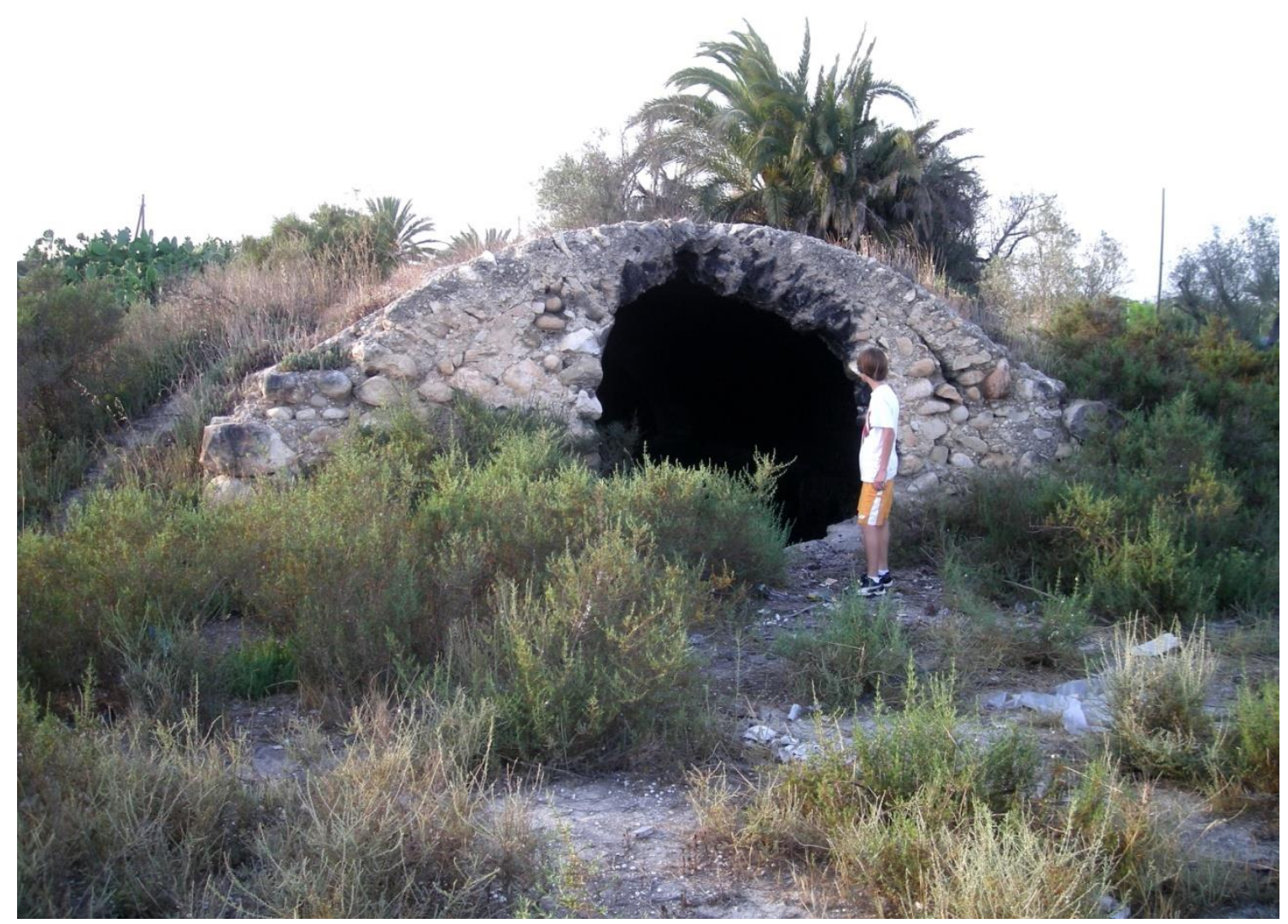

Fig. 17. Aljibe del Cipré. Lado septentrional. 


\subsection{El Aljibe del Cipré}

Se trata de un voluminoso depósito subterráneo situado al final del circuito hidráulico andalusí, en la partida del Derramador, cerca del saladar del Fondo, a unos $7 \mathrm{~km}$ del manantial de La Font Antiga (Fig. 17).

El edificio, de planta rectangular, tiene unas dimensiones de 19,20 m de largo por 6,40 de ancho. Alcanza una profundidad desde el nivel de coronación hacia el fondo de más de 5 metros. Sus paredes son de mampostería de cal y piedra, sobre las que se eleva una bóveda de cañón de arco de medio punto rebajado. La bóveda alcanza en altura los 2,50 m desde el nivel suelo hasta la cima (Fig. 18). Está construida mediante un encofrado de hormigón de cal. Presenta en su interior dos arcos fajones, también de hormigón, que descansan sobre sendas pilastras de mampostería de forma redondeada. Las paredes en su interior de se hallaban enlucidas con cal hidráulica impresa con cantos y pintadas de almagre impermeabilizante, todo muy similar a las galerías del Qanāt 1. La parte superior de la bóveda de hormigón cuenta con cinco orificios de ventilación.

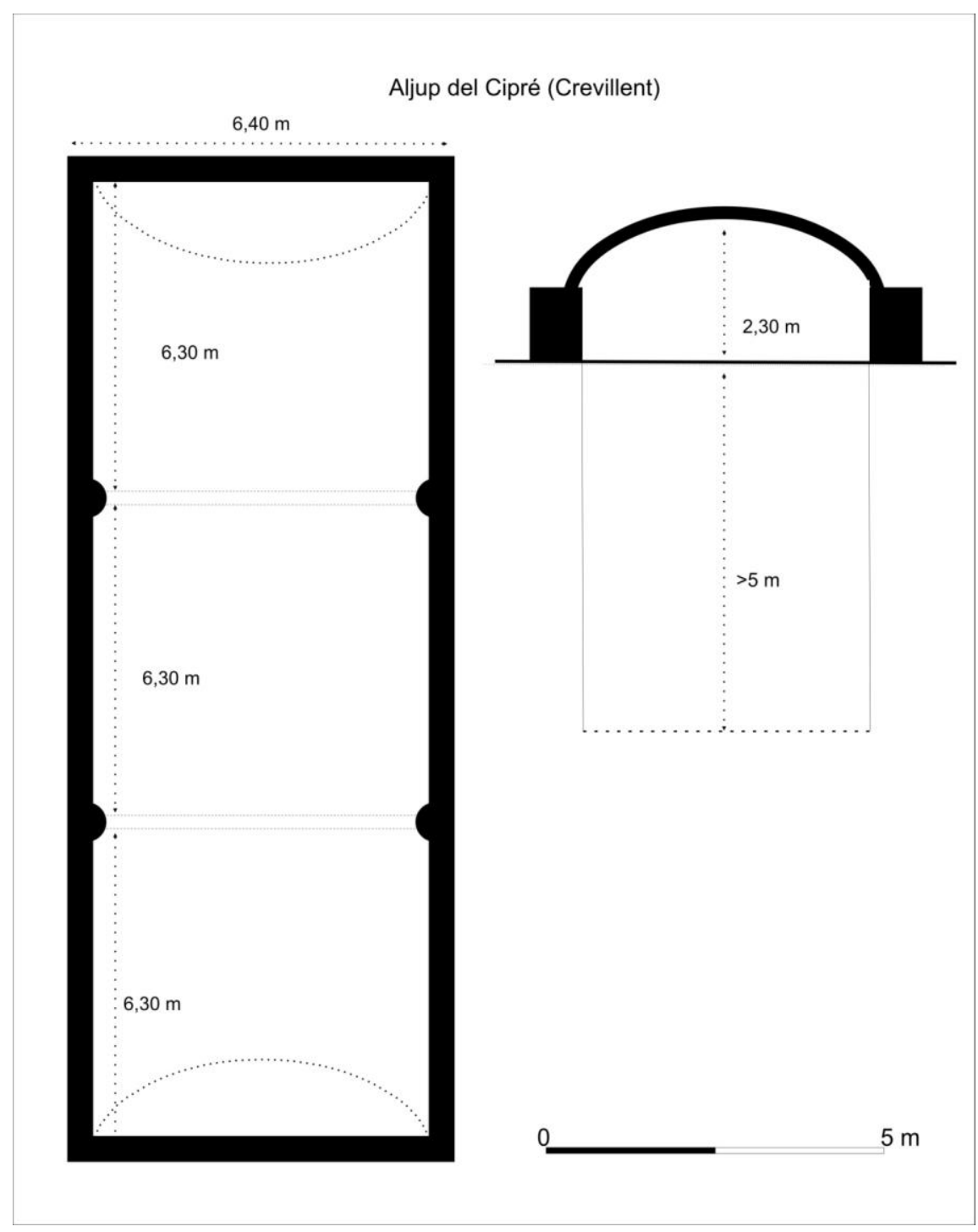

Fig. 18. Aljibe del Cipré. Croquis de la planta y sección. 
Estos aljibes rurales se alimentaban generalmente de las acequias, como lo prueba una pequeña compuerta que hemos localizado en su boca septentrional. No obstante, la mayoría de ellos contaban además con extensas redes de regueros efímeros construidos por los regantes que recogían y conducían las aguas pluviales y de escorrentía hacia el depósito. Normalmente previa a la boca de entrada del aljibe, existía una o varias piletas de decantación que retenían los sedimentos más groseros. El agua de estos aljibes se utilizaba especialmente para saciar la sed de las personas y animales. Cada uno de ellos contaba al menos con un poyo y pila donde colocar los cántaros y también con un abrevadero para el ganado tallado en piedra, como el que existió en El Aljibe del Cipré, que fue robado hace unas décadas. Existen notas del Consell de la villa en el siglo XVIII sobre reparaciones y horas de agua para su llenado, de ello deducimos que era un servicio de dominio público. Este aljibe se utilizó hasta el siglo XIX. Fue vital para abastecer a los habitantes de la partida, pero también a diligencias, carros y caballerías que transitaban por el vecino el Carril Real que comunicaba Elx con Orihuela. También era parada obligatoria para los extensos ganados que acudían a abrevar procedentes del Bajo Aragón y Serranía de Cuenca. Como dato anecdótico, diremos que la persona que nos comunicó el nombre de este monumento olvidado, Antonio Ferràndez, álias Pallissa, en 2004, nos explicaba emocionado que de niño, allá por 1920, cuando se hallaba ya vacío, solía acudir con sus amigos a jugar a frontón valenciano en su interior. Esta anécdota quizás nos ayude a comprender como son de espectaculares sus dimensiones. En la actualidad se halla en un estado lamentable, repleto de basura y desechos industriales, que regularmente son quemados (Fig. 19).

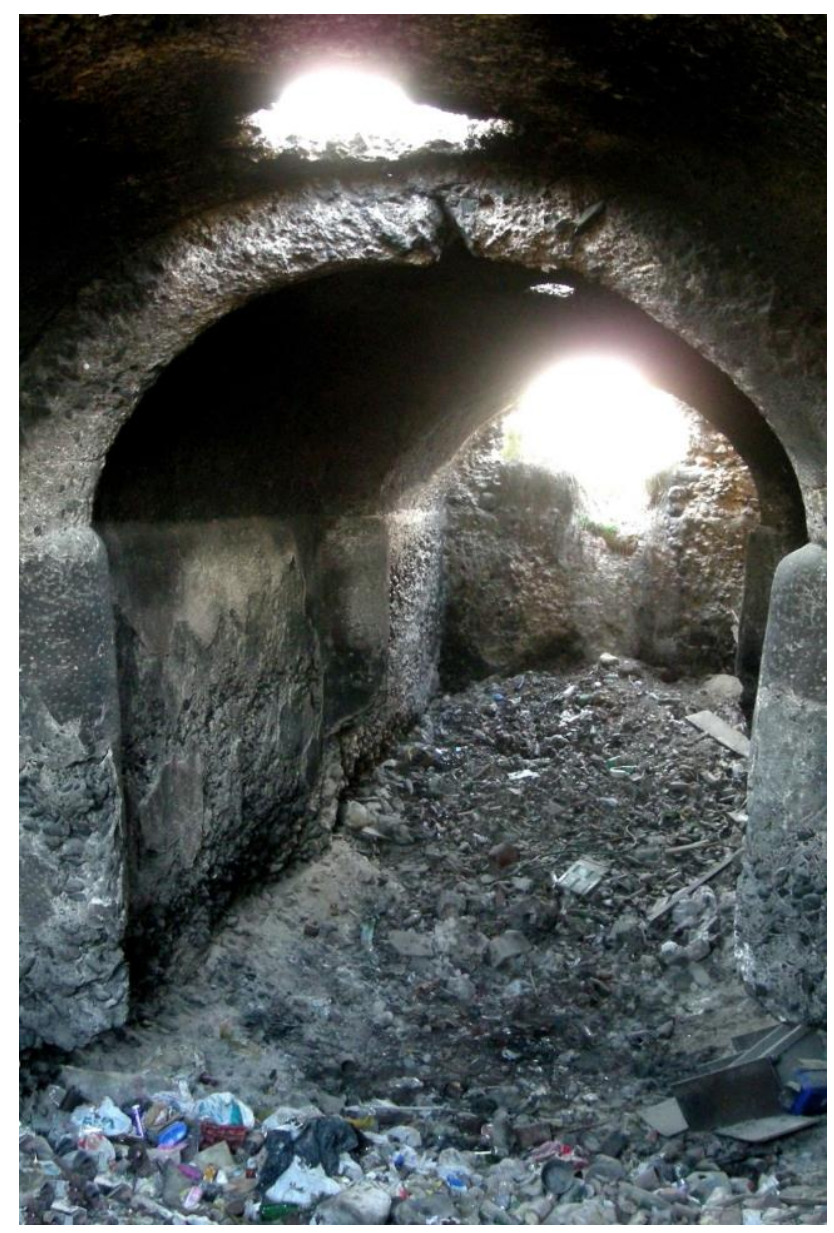

Fig. 19. Interior del Aljibe del Cipré. 


\section{Una aproximación cronológica}

La campaña de excavación y prospección nos ha proporcionado diversas pistas que, sin ser concluyentes, nos ayudan a situar el conjunto de La Tanca del Forat dentro de un lapso que iría del periodo emiral para algunos elementos, a otro menos preciso que llamaremos andalusí-sensu lato.

Los sondeos llevados a cabo en el molino de La Tanca del Forat proporcionaron diversos objetos prehistóricos descontextualizados. El vaciado del cárcavo resultó más fructífero ya que descubrimos un fragmento de muela de molino de unos $90 \mathrm{~cm}$ de diámetro. Este tipo de muelas de reducido tamaño, la tipología del cárcavo y la plataforma del molino, y el hecho de estar todo ello conectado al sistema de acequias andalusíes que discurre por el nivel inferior del valle, son sólidos argumentos para considerar la construcción como de época andalusí, y más preciso, entre época emiral y el siglo XI. Por contexto constructivo, dimensiones y ausencia de noticias medievales, pensamos que también el molino de Els Pontets, debiera datarse con similar adscripción.

El análisis arqueológico del azud también es de gran interés. Puesto que el sondeo que realizamos en uno de sus estribos no libró ningún material arqueológico, tuvimos que centrar nuestros esfuerzos en intentar desentrañar algo de su cronología a través de otros indicadores, especialmente de su arquitectura. Ya hemos comentado más arriba que el dique se construyó con pesados sillares muy heterogéneos, un material claramente reaprovechado. Por el momento no estamos en condiciones de poder averiguar la procedencia de estos bloques. Bien podrían haber sido arrancado de algún monumento romano de las inmediaciones que desconocemos, o bien incluso de algún elemento hidráulico islámico anterior. Eso ya se verá. Por ahora en aquello que hace falta fijar la atención es en la forma tan peculiar como se colocaron los sillares, puesto que el aspecto formal en arquitectura también deviene un signo temporal. En una primera aproximación el monumento nos recordó la obra de las denominadas "peixeres" que tanto proliferaron en Catalunya y norte de País Valenciano durante los siglos bajo medievales (Batet, 2006). En ese caso, el azud debiera haber sido levantado por los conquistadores feudales durante los siglos XIV y XV. Sin embargo, este tipo de paradas, toda vez que el nombre alude a una multitud de tipologías y sistemas constructivos diacrónicos, la gran mayoría de ellas utiliza bellos sillares de módulo regular dispuestos en hiladas de gran regularidad. En nuestro caso, ambas características estaban ausentes. Por el contrario, aquello que hacía distinto al azud era su "desorden" tanto de materiales como de aparejamiento de los mismos. Varios autores han constatado estos mismos aspectos en numerosos monumentos primitivos islámicos. Fortificaciones, puentes, mezquitas de la primera época musulmana utilizan amalgamas de materiales reciclados (Pavón Maldonado, 1999).

Recientemente, Rafael Azuar ha sistematizado las diversas técnicas constructivas de la fase formativa de Al-Andalús (Azuar, 2005). Según el autor, en un primer momento relacionable con el emir Abd Ar-Rahman I, parece fue común la utilización de piedras reutilizadas de monumentos romanos y visigodos. Los sillares apenas se modificaban, dado que se carecía de mano de obra especializada en cantería. Se colocaban en seco en esquinas, montantes y contrafuertes, recibidos a veces con barro,. En la mezquita de Córdoba, aún dentro del gobierno de este emir, se advierten los cambios arquitectónicos que darán lugar a la segunda fase: aparejo colocado a soga y tizón y concertación de sillares, esto es, encaje de 
bloques heterogéneos mediante desbastados y pestañas. Estas características, junto con el empleo de los morteros de cal, conformarían las principales distinciones del segundo momento que coincide con el emir Abd Ar-Rahman II. Salvando las distancias, en nuestro modesto azud de La Tanca del Forat tendríamos un testimonio del nuevo programa nacido en el siglo IX. La superficie de la pared es pequeña, pero suficiente para detectar todo aquello que hemos reseñado. También parece que la soga y tizón formó parte del muro, según se desprende de las marcas dejadas por el mortero y la disposición de los sillares que aún permanecen in situ.

Otra evidencia de su primitiva cronología es que se trata de una presa de gravedad, rectilínea, sin contrafuertes, la resistencia de la cual viene dada por su propio peso. Es cierto que en los siglos XVII y XVIII aún se levantaron varios diques de gravedad (Pérez Medina, 2002), pero la asociación obligatoria que mantiene nuestro azud con el funcionamiento del molino y acequia andalusí es determinante. Resulta tentadora la idea de relacionar los constructores de este azud con el inmediato poblado emiral del Forat Oeste ${ }^{6}$, es algo que necesitará de mayor profundización, pero es significativo que gran numero de objetos cerámicos similares a los que se documentan en este yacimiento se esparcen en las orillas de las viejas canalizaciones.

Hemos nombrado reiteradamente la acequia mayor andalusí. Su adscripción vino con motivo de hallarse conectada al Qanät 1 de Miquel Barceló (Barceló). Esta canalización es la que discurría por el primer piso del acueducto de Els Pontets y que fue amortizada al trazarse un nuevo canal superior en el siglo XIX. Quedaban varios lugares donde se hacía difícil identificarla: encontrábamos superpuestas distintas obras, aparentemente semejantes debido a su coloración rojiza, en teoría musulmana. Este es el caso de las inmediaciones del molino y azud de La Tanca del Forat. Después de numerosas prospecciones y reconocimientos de la obra, localizamos varios fragmentos de cerámica murciana de la primera mitad del siglo XVIII incrustados en el mortero de cal de la acequia superior (Matilla Seiquer, 1992), (Fig. 20).

Estos valiosos objetos coincidirían con la documentación que asegura que la administración del Duque de Arcos en 1759 da la orden para ejecutar las obras del nuevo canal. Para la construcción de esta acequia dieciochesca además de cerámica doméstica, se reutilizaron grandes trozos de ladrillos que habían formado parte de la acequia inferior, andalusí a la cual anula y se le superpone (Fig. 21).

Prospectada también la acequia inferior, no hemos podido localizar ningún material cerámico o fósil-guía lo largo de su recorrido, pero tenemos datos que refuerzan la antigüedad que venimos proponiendo. De partida, sabemos que es anterior a 1759, pero todavía podemos retroceder más. En 30 de Enero de 1624 se realiza una asamblea general en el castillo de Crevillent en la que participan representantes de la administración feudal, el Consell local y diversos vecinos para tratar sobre la necesidad de reparar y mejorar la acequia "... ya que mucha parte de las dichas aguas está perdida desde antes de la expulsión de los moros" (Puig Fuentes, 2000). Hacía apenas una década que habían llegado a la localidad más de cien familias de cristianos con la intención de ocupar el lugar dejado por los moriscos. Entre los argumentos para justificar las obras está la de recuperar el caudal que por lo visto se pierde a cusa de fugas y roturas. En el informe se garantiza que “...Su Excelencia ha de-

\footnotetext{
6 Sobre la cronología del yacimiento del Forat y su repertorio cerámico y numismático, vid.: (Gutiérrez Lloret, 1996; Trelis Martí, 1994). El poblado se halla bien datado por un dírbam de Abd Ar-Rahman II acuñado en Córdoba en 851-852 (Domènech \& Trelis, 1993).
} 
terminado de cobrarla (el agua) y guiarla, aciendo y gastando de su hacienda... para conseguirle reparar el acequia y levantar las paredes de ella". A parte del agua que se perdía por las canalizaciones había que contar con la que afloraba de los manantiales subálveos y que por lo visto se perdía por el cauce. Sin embargo, la subvención para efectuar la reparación nunca llegó y los vecinos hubieron de seguir utilizando las acequias de los "moros".

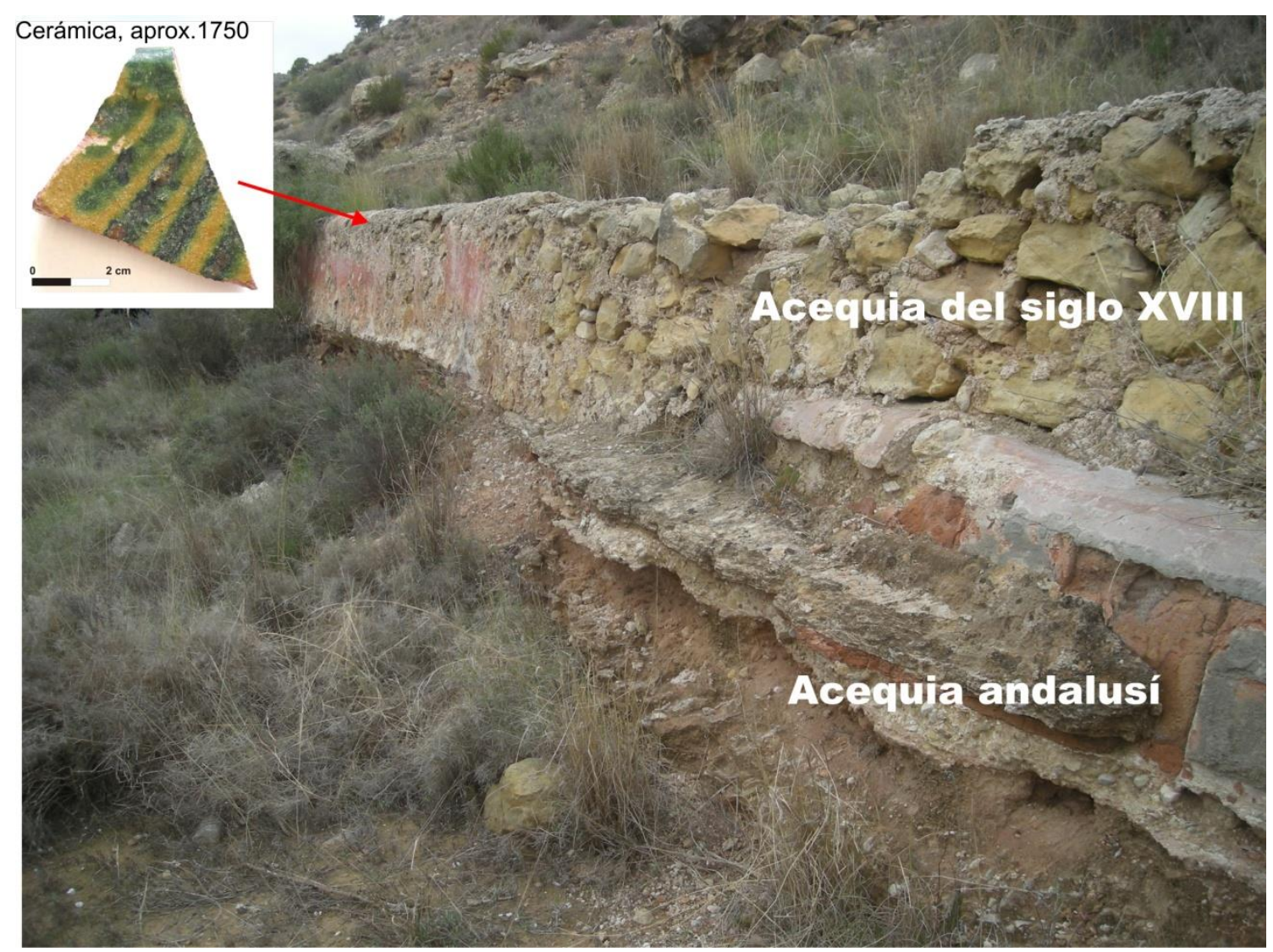

Fig. 20. Fragmento de cerámica del s. XVIII hallada en el mortero de la acequia superior.

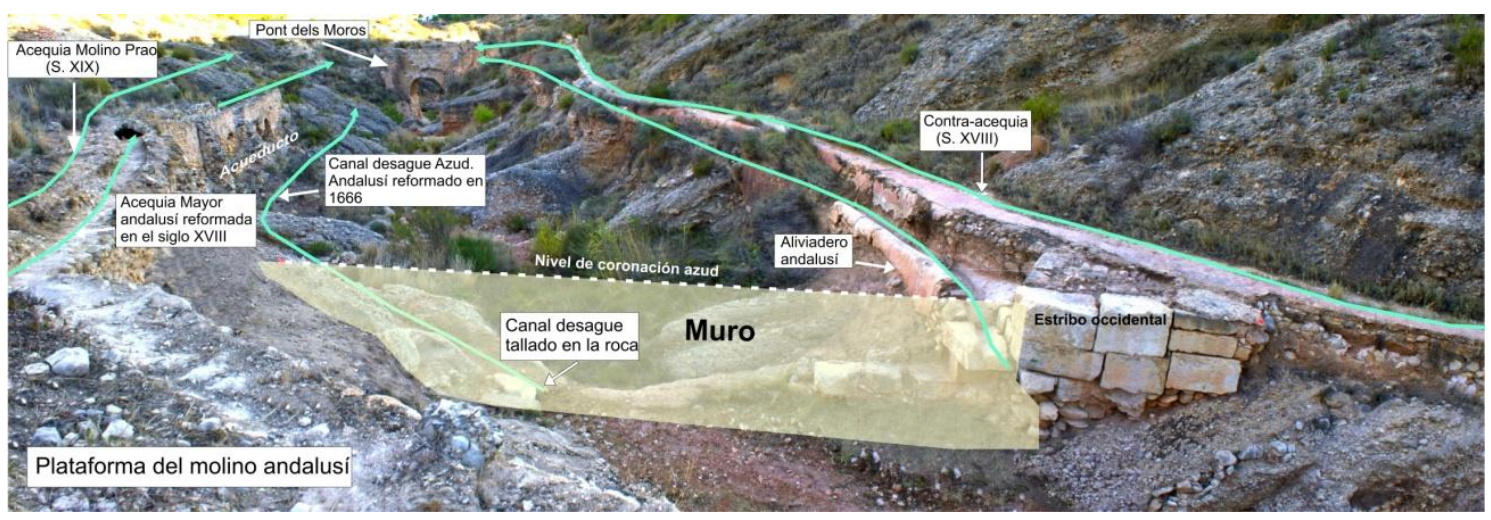

Fig. 21. Secuencia constructiva y partes más destacadas del conjunto de La Tanca del Forat.

En 1666 un informe pericial determina que casi nada ya se debe salvar de la obra antigua, especialmente el tramo desde ..."presa-suponemos azud de La Tanca del Forat- fins lo partidor de Mateu Joan", dado que ..." dita séquia se n'ix per tota ella al barranch més de la quarta part de l'aygua"... y ..."la serra és arenisca y que es sunmix l'aygua y se n'ix al barranc a bón no's pot aprofi- 
tar". En este documento se enumeran minuciosamente los materiales de construcción, los hornos de cal, pintura y hasta las cajoneras o moldes necesarios para construir la nueva acequia, que en gran medida sería de ladrillo. Finalmente, la empresa se llevó a cabo y podemos dar testimonio de ella. Sin embargo los miles de ladrillos que iban a conformar la nueva acequia tan solo sirvieron para reparar ciertos tramos de la acequia que los colonos habían heredado de los musulmanes. Se constatan estos materiales, identificados por las medidas aproximadas que aparecen en el informe -de pam y mig en quadre- desde el mismo canal de desagüe del azud de La Tanca del Forat hasta la localidad. Así pues, los ladrillos se convierten en un elemento identificador, a priori, de la acequia andalusí reparada.

En consecuencia, podemos decir que gran parte del primitivo sistema andalusí estuvo en funcionamiento hasta mediados del siglo XVIII, momento en que se excavan nuevos pozos y se crean nuevas conducciones con cajero de mayor capacidad, de hasta $80 \mathrm{l} / \mathrm{s}$, situadas a una cota más elevada, evitando siempre el lecho del barranco. Esta nueva acequia, también pintada de almagre, aunque de tono más granate, fue la que recorrió y admiró al ilustrado Cavanilles (1797).

Sobre los azudes de La Tanca dels Nicolassos, La Séquia Fonda y La Terrera, su fecha de construcción no se muestra tan clara. Podríamos deducir que se trata también de obras andalusíes, puesto que trasvasaban sus aguas a la acequia mayor de esa época. Pero como hemos ido viendo, las canalizaciones musulmanas estaban funcionando aún en el siglo XVIII. En tanto no van asociados a ningún molino medieval, nos queda la duda de si fueron obras modernas de reconducción de aguas superficiales hacia la acequia mayor para aumentar su caudal, tal y como aconsejaban los informes periciales del siglo XVII. Sobre el resto de edificaciones hidráulicas que presentamos, harán falta nuevos estudios en profundidad, especialmente arqueológicos y de contexto, para situarlos en su ámbito histórico correcto.

\section{Referencias}

Arnau, B. \& Martí, J. (2000): Aigua i desenvolupament urbà a Madinat Balansiya (València). L'excavació d'un molí hidràulic de l'època califal. Ed. Th. Glicket alii. Els molins hidràulics valencians. Tecnologia, història i context social, pp. 165-192.

Azuar, R. (2005): Las técnicas constructivas en la formación de al-Andalus. Arqueología de la Arquitectura, ISSN 1695-2731, No 4, en: Aparejos constructivos medievales en el Mediterráneo Occidental: estudio arqueológico de las técnicas constructivas), pp. 149-160.

Batet, C. (2006): Agricultura i dominació feudal en un espai hidràulic andalusí. L'aigua conquerida: Hidraulisme feudal en terres de conquesta. Universitat Autònoma de Barcelona y Universitat de València, pp.131-174.

Barceló, M. Carbonero, M. A.; Martí, R.; Rosselló-Bordoy, G. (1988): La Font Antiga de Crevillent: ensayo de descripción arqueológica. Áreas, 9: 217-231.

Barceló, M.; Kirchner, H.; Lluró, J.C. (1988, b): La Arqueología Medieval. En las afueras del medievalismo. Barcelona.

Carbonero, M. A., Cressier, P. i Erbati, L. (1997): Un ejemplo de transformación radical y planificada del paisaje agrario: Tagsa (Chefchaouen, Marruecos. Transformaciones agrarias en Andalucía orientaly norte de Marruecos, pp. 63-105. 
Cavanilles, A. J. (1797): Observaciones sobre la bistoria natural, geografía, agricultura, población y frutos del Reyno de Valencia, Madrid.

Domènech, C. \&Trelis, J. (1993): Hallazgos numismáticos de la época islámica en Crevillent (Alicante). Jarique de numismática hispano-árabe, III: 333-345.

Escolano, G. (1611): Década primera de la historia de Valencia. Libros VI y VII, parte segunda, Valencia.

Ferrer i Mallol, $\mathrm{M}^{\mathrm{a}}, \mathrm{T}^{\mathrm{a}}$. (1988): Les aljames sarrä̈nes de la Governació d'Oriola en el segle XIV. Inst. Milà i Fontanals. Barcelona.

Gea Calatayud, M. (1990): Sistemas de captación y distribución de agua de probable origen árabe, en Albatera y Crevillente. Sharq Al-Andalus. Estudios Arabes, 7: 175-194.

Glick, T.; Guinot, E.; Martínez, L. P. (2000): El patrimoni hidràulic valencià. Els molins bidràulics valencians. Tecnologia, història i context social, pp. 29-99.

Guinot, E.; Selma, S. (2003): Las acequias de Elche y Crevillente, Conselleria d'Agricultura Generalitat Valenciana, València.

Gutiérrez Lloret, S. (1996): La cora de Tudmir: de la antigüedad tardía al mundo islámico: poblamiento y cultura material. Casa de Velázquez, Madrid.

Lagardère, V. (1991): Moulins d'Occident musulman au Moyen âge (IX au XVe siècles): al-Andalus, Al-Qantara, XII: 59-118.

Markham, R. (1991): El regadiu de l'Espanya de l'Est (1867) Institució Valenciana d'Estudis i Investigació, Diputació de València, València.

Matilla Séiquer, G. (1992): Alfarería Popular en la Antigua Arrixaca de Murcia. Los Hallazgos de la Plaza de San Agustin (ss. XV-XVII), Murcia.

Menargues, J. (2005): El molí de l'infant Martí. Rev. MiC de Crevillent: 173-175.

Menargues, J. (2009): La toponímia dels mudèjars i moriscs de Crevillent registrada en els documents cristians, Societat d'Onomàstica: Butlletí interior, 115: 131-148.

Menargues, J. (2012): Excavació, neteja i topografia de les estructures hidràuliques de la Tanca del Forat (Crevillent, Alacant). Memòria Final. N. Exp. : 2011/0597-A. Conselleria d'Educació, Cultura i Esport. Alacant.

Menargues, J. (2014): Intervencions arqueològiques a la Font Antiga de Crevillent: assuts i molins andalusins a la Tanca del Forat, Recerques del Museu d'Alcoi, 313: 77-94.

Oliver Narbona, M. (1983): Molinos harineros de agua. Universidad de Alicante, Caja de Ahorros de Alicante y Murcia, Alcoi.

Pavón Maldonado, B. (1999): Tratado de arquitectura hispano-musulmana. CSIC, Madrid. 
Pérez Medina, T. (ed.) (1999): Petits embassaments valencians del segle XVIII, Cuadernos de Geografía de la Universitat de València, 71: 11-30.

Puig Fuentes, S. (2000): La institución por excelencia: la Font Antiga. Crevillent-Séquia: Simbiosis histórica. Rev. MiC. deCrevillent: 209-211.

Selma, S. (1993): Els molins d'aigua medievals al Sharq al-Andalus, Onda.

Selma, S. (2000): De la construcción islàmica al casilici modern: l'evolució del molí hidràulic valencià. Ed. Th. Glicket alii. (eds.): Els molins hidràulics valencians. Tecnologia, història $i$ context social, pp. 101-161.

Trelis Martí, J. (1990). Aproximación al poblamiento de Crevillent en los siglos XIII-XIV. Rev. Setmana Santa de Crevillent: 80-81.

Trelis Martí, J. (1994). Aproximación a la transición del mundo tardoantiguo al islámico en las comarcas meridionales del País Valenciano: el ejemplo de Crevillente (Alicante). Actas del IV Congreso de Arqueología Medieval Española, pp. 309-316. 